\title{
How COVID-19 Has Influenced the Purchase Patterns of Young Adults in Developed and Developing Economies: Factor Analysis of Shopping Behavior Roots
}

\author{
Alexander Rossolov ${ }^{1, * \mathbb{D}}$, Yevhen Aloshynskyi ${ }^{2}$ and Oleksii Lobashov ${ }^{1}$ \\ 1 Department of Transport Systems and Logistics, O.M. Beketov National University of Urban Economy in \\ Kharkiv, Marshala Bazhanova St. 17, 61002 Kharkiv, Ukraine; lobashov61@gmail.com \\ 2 Department of Transportation Systems, Faculty of Civil Engineering, Cracow University of Technology, \\ 31-155 Kraków, Poland; yevhen.aloshynskyi@pk.edu.pl \\ * Correspondence: rossolovalex@gmail.com
}

check for updates

Citation: Rossolov, A.; Aloshynskyi, Y.; Lobashov, O. How COVID-19 Has Influenced the Purchase Patterns of Young Adults in Developed and Developing Economies: Factor Analysis of Shopping Behavior Roots. Sustainability 2022, 14, 941. https:// doi.org/10.3390/su14020941

Academic Editor: José

Alberto Molina

Received: 30 October 2021

Accepted: 11 January 2022

Published: 14 January 2022

Publisher's Note: MDPI stays neutral with regard to jurisdictional claims in published maps and institutional affiliations.

Copyright: () 2022 by the authors. Licensee MDPI, Basel, Switzerland. This article is an open access article distributed under the terms and conditions of the Creative Commons Attribution (CC BY) license (https:// creativecommons.org/licenses/by/ $4.0 /)$.

\begin{abstract}
The paper presents survey results from shopping behavior transformation in developed and developing countries due to the COVID-19 pandemic outbreak in spring 2020. The survey includes the polling process that covered 515 and 117 young adults, respectively, for two economies and factor analysis to determine the latent intentions of purchase behavior. Shopping patterns were studied for food, medicine, goods of first priority, electronics, clothing, and shoes. According to factor analysis results, we determined nine factors that reveal some similarities in shopping behavior as pro-safe purchases and belt-tightening patterns for both economies. Along with that, we revealed that people from developed countries perceived the greater danger and fear due to the COVID-19 crisis than young adults from developing economy. Based on polling results, the post-COVID-19 shopping channel choice behavior was evaluated for developed and developing economies.
\end{abstract}

Keywords: shopping behavior; purchase and delivery channels; polling; COVID-19; factor analysis

\section{Introduction}

Since March 2020 society around the globe was forced to change its routine activities. The pandemic COVID-19 has caused it. The governments of the countries of Eurasia, Africa, Australia, North and South America have deployed a list of measures to reduce the spread of the coronavirus SARS-CoV-2. These measures were related to the reduction of social contacts resulting in "stay-at-home orders". The lock-down introduction changed people's activities in the fields of mobility [1-3], shopping [4-7] and working activity [8,9]. The transportation sector was forced to adjust its operations for goods supplies [10-12] as they became vital for people's lives in pandemic times. The rapid rise in demand for a list of goods during the first wave of COVID-19 caused the deficit in the retail system making substantial pressure on the supply chain and, first of all, on last-mile logistics. This part of the supply chain faced new challenges in the pandemic outbreak caused by shopping behavior change of end-consumers while the pre-pandemic sustainable issues of last-mile logistics still stand [13-16]. The rapid shift of the consumers around the globe to online services only worsened the sustainable features of e-commerce as the demand for home delivery services significantly grew up. The roots of new shopping behavior, the knowledge on new features of the households' consumption for a list of products became of great importance to promote the appropriate measures for leveling the unsustainable character of the last-mile logistics in such times of crisis as the COVID-19 pandemic.

This field of study became a spotlight for marketing and transportation scientists from the very beginning of the COVID-19 outbreak. Two main branches of the studies can be distinguished for the shopping behavior change issue. The first one considered the ways to reveal the shopping behavior through the description of the interconnection between socio-demographic data of 
end-consumers and their purchase patterns in the pandemic crisis [7,17-21]. The studies from the second branch were focused on finding the latent roots of the shopping behavior change [4,22-24]. Both branches greatly contributed to the knowledge of why shopping behavior got the stockpiling features $[6,17,24]$, what goods became of high importance for households $[6,7,17,25]$ and what kind of shopping channel was preferable for people during the pandemic $[4,20,26,27]$. Despite an extensive list of studies already made in the shopping behavior field during the pandemic, the issues of differences in consumers' purchase patterns in light of the economies remain uncovered. The generic features and differences of the shopping behavior of end-consumers and their drivers in the developed and developing countries are the key questions to be revealed. Moreover, as senior people were considered the most vulnerable due to COVID-19 infection, the focus of some studies was attracted by the problems of aged persons [28,29]. However, the tremendous pressure due to the COVID-19 crisis's aftermath, such as business closure and jobs cut, was perceived first of all by the young adults. People from this age group can be considered the most vulnerable category during the crisis as they are less stress-resistant than their parents [30]. Leck of the studies in this field allows us to fill the gap by revealing the influence of COVID-19 on young adults from the point of their shopping behavior change.

In the light of the described problem, a list of issues should be solved that can be depicted with the following questions. Were the same drivers of young adults' switch from in-store shopping to online channels during the COVID-19 outbreak in the developed and developing economies? Did young adults perceive the same level of fear during the pandemic, and how did this influence their attitudes towards shopping channel choice? Did they face the same economic pressure caused by the COVID-19 pandemic, and did it affect their shopping behavior? Given the different levels of e-commerce penetration in the developed and developing economies [31,32], the comparison of drivers for shopping channel choice in the pandemic time has colossal importance for post-pandemic last-mile logistics resilience. It will allow us to assess the potential changes in shopping channel choice and understand whether the shift to online channel has permanent features or can be considered just like a forced response to COVID-19 reality.

The paper is structured as follows. Section 2 is the background of this study, which contains two subsections. The first one provides the substantiation of the pandemic influence on shopping behavior from the point of crisis phenomenon. The second subsection aims to reveal the problem of the shopping channel choice by the end-consumers in pre-pandemic time. The methodology of this study is presented in Section 3, which comprises the description of the concept, research techniques, and survey structure. Section 4 provides the results on descriptive analysis of data in regard to purchasing activity before and during the pandemic outbreak, i.e., shopping channels choice, purchase frequency, and transport mode choice used by consumers for shopping commuting. Moreover, Section 4 contains the factor analysis results with a detailed description of the factors extraction and their interpretation. In Section 5, we discussed the similarities and differences of the consumers' shopping behavior, considering developed and developing economies. Also, we pointed on the limitations of this study within this section. Section 6 contains the conclusions made on the conducted study.

\section{Background}

\subsection{Crisis, Risk and Consumer Behavior}

The time of crisis has always produced fears and stress resulting in disruption of the citizens' mental and physical health, economic and social life. In general, the risk reflects the likelihood of the possible outcomes [33]. It describes neither negative nor positive aftermaths of the events; instead, it estimates the probability values to achieve some results or occurrence of certain events. The application of risk assessment for social systems shapes it with a dark side by interpreting the predicted probability. The impact of the perceived risk by the people is well studied in the frame of economic (marketing and retail) [34-36] and social science [37-40]. The common feature of all studies concerning risk and crisis lies in the reflection of the people's reaction to some deprivation and possible loss of health (and 
sometimes life), money, or property. The spread of the virus SARS-CoV-2 (COVID-19) forms similar dangerous conditions for people's health as it occurs under a disaster and may be attributed to an anthropogenic crisis type [41]. The imposed lockdown measures in the situation of COVID-19 may cause suffering even of healthy people due to severe restrictions in mobility and regular supply. The long duration of the "stay-at-home" orders in the countries around the globe and constant media broadcasting of the pandemic situation increase the people's psychological tension.

In the case of the pandemic, special attention should be made to consumer behavior. The panicked perception of the crisis can provoke the domino effect resulting in additional pressure on the supply chain. Human behavior in times of economic crisis is well studied by the scientists for both developed [42-46] and developing economies [47-50]. The Great Depression (from 1929 until the late 1930s) may be pointed out as the worst economic crisis in the history of the industrialized world. It affected both developed and developing countries around the globe, causing massive disruption in peoples' lives. According to Mishkin [42], the balance sheet of the USA households changed dramatically at the beginning of the Great Depression, reflecting transformations in consumer behavior. Given that people reduced their expenditures by 22 cents on durable goods under a condition in which household liabilities increased to one dollar, the author explains this with consumers' fear of losing solvency shortly. This finding of consumer behavior change complements the studies made by Romer [43], Mian and Sufi [45]. For instance, Romer [43] found that during the crisis and under uncertainty, people cut back on purchasing durable goods and focusing only on the first priority commodities and food. Mian and Sufi [45] estimated the tendency of the US counties with high household leverage to spend less on durable consumption during the recession of 2000. In contrast, such an effect was not detected for the counties with low household leverage.

The recent economic crisis in 2008 has had different aftermath and impact on society compared to the Great Depression, especially on some age groups. Thus, according to David G. Myers, the adult youth of the 1990s was less stress-resistant compared to their parents [30]. People from this age group were influenced more by stress and intended to depression. This feature played an essential role during the economic crisis of 2008 when young adults perceived a massive consumer depression because of the social problems and adaptation [47]. Such effect should be studied in the case of the COVID-19 situation since the generation of the 2000s is supposed to be the most easily influenced group of workers as it is less experienced and qualified than more aged groups. They risked being fired during the first wave of the lockdown in spring 2020, for instance, in the UK and USA.

As for the developing economy, consumer behavior is quite similar during crisis time as observed for developed countries. For instance, Turkish consumers have cut down on expenditures at the beginning of the 2008 crisis by shifting to the goods within the categories from high to low price [49]. The quality of the products was not crucial for buyers in this case. Moreover, a study made by Turcinkova et al. [50], which covered 27 European countries (both developed and developing), has revealed the high-risk perception of poverty and material deprivation by the people during the economic crisis of 2008. Financial risk and fear of loss of solvency made the properties of consumer goods unnecessary.

According to an analytical study made, we can conclude that COVID-19 can be identified as a crisis that changed consumers' behavior and its effect on last-mile logistics. We have to define the depth of the changes in people's purchase behavior, the level of the transformations in the buying commodities list and assess the switch in choices for purchase and delivery channels. To do that, we have to reveal the pre-pandemic end-consumers behavior regarding the purchase channels choice for different commodities.

\subsection{Online and In-Store Channels Choice Attributes}

Consumer behavior about the purchase and delivery channel choice interested academia since the worldwide Internet deployment around the globe started [5,13,14,31,32,51-67]. Urbanization also contributed significantly to the e-commerce penetration into the urban 
supply chain $[52,68]$. The home delivery service, together with e-commerce, made a revolution in consumerism and urban logistics, especially in developed countries. The studies, as mentioned above, covered an extensive list of countries resulting in the determination of socio-demographic attributes to be valuable for predicting end-consumer behavior. The analysis and systematization of the studies on purchase channel choice were summarized in Table 1. It reflects the statistically significant socio-demographic attributes.

Table 1. Socio-demographic attributes on purchase channel choice based on literature review.

\begin{tabular}{|c|c|c|c|c|c|c|c|c|c|}
\hline \multirow[b]{2}{*}{ Author(s) and Reference } & \multirow[b]{2}{*}{ Country(ies)/City(ies) } & \multirow[b]{2}{*}{ Economy } & \multicolumn{7}{|c|}{ Attributes } \\
\hline & & & 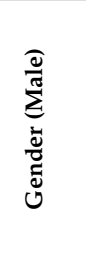 & $\stackrel{\infty}{4}$ & : & 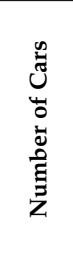 & 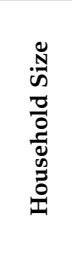 & 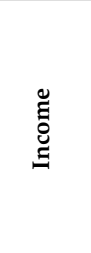 & 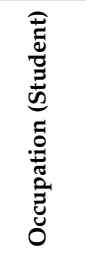 \\
\hline Beckers, Cárdenas, Verhetsel [5] & Belgium/NA & Developed & Online & & Online & & & & \\
\hline Schmid and Axhausen [31] & Switzerland/Zurich & Developed & & & & & & Online & \\
\hline Farag, Krizek, Dijst [54] & $\begin{array}{l}\text { Netherlands/Utrecht and } \\
\text { USA/Minneapolis }\end{array}$ & Developed & Online & & & & & Online & Store \\
\hline Soopramanien and Robertson [55] & $\begin{array}{l}\text { UK/Lancaster, Morecambe, } \\
\text { Brighton, Hove }\end{array}$ & Developed & & Store & & & & Online & \\
\hline Weltevreden [56] & Netherlands & Developed & & Store & & & & & \\
\hline Hsiao [57] & Taiwan/NA & Developing & & Store & & & & & \\
\hline Cao, Chen, Choo [58] & USA/Minneapolis & Developed & & & & Store & Store & Online & \\
\hline Lian and Yen [59] & Taiwan/NA & Developed & Online & Online & & & & & \\
\hline Comi and Nuzzolo [60] & Italy/Rome & Developed & Online & & & & Store & & Online \\
\hline Zhai, Cao, Mokhtarian, Zhen [63] & USA/Minneapolis & Developed & & Store & Online & & & Online & \\
\hline Maat and Konings [64] & Netherlands/Leiden & Developed & Online & Online & Online & & & & \\
\hline $\begin{array}{l}\text { Hood, Urquhart, Newing, } \\
\text { Heppenstall [65] }\end{array}$ & Great Britain/NA & Developed & Online & Online & & & & & \\
\hline Loo and Wang [66] & China/Nanjing & Developing & Store & Store & Online & & & Online & \\
\hline Zhen, Cao, Mokhtarian, Xi [67] & China/Nanjing & Developing & Store & & & & & Online & \\
\hline
\end{tabular}

The studies made by Swaminathan et al. [51], Rohm and Swaminathan [53], van Duin et al. [61] have not been included in Table 1 as they focused on the assessment of the online shopping security perception by the end-consumers and quality of last-mile delivery within the urban area. Nevertheless, these problems are still actual and complement the e-commerce development issue.

As the result of the literature review, we have defined that in regard to socio-demographic attributes, the factor "gender" with the specification to the gender "male" gives an-onlineoriented positive effect $[5,54,59,60,64,65]$. While males from developing countries tend to the store shopping [66,67]. Along with that, the factor "income" has the strongly pronounced online channel orientation, meaning that an increase of the personal and household income will result in an orientation to online shopping [31,54,55,58,63,66,67]. According to studies made by Zhai et al. [63], Maat and Konings [64], Loo and Wang [66], the education attribute positively impacts online channel choice, under the condition when the end-consumer has at least a high education level.

The contradictory effect in the in-store/online channel choice frame was defined for the factor "age". For instance, the findings of Soopramanien and Robertson [55], Weltevreden [56], Hsiao [57], Zhai et al. [63], Loo and Wang [66] pointed out that an increase in the end-consumer age confirms the intentions to buy in the physical store. This has some correlation with estimates of household size [58,60], i.e., confirming that increasing the number of household members has a positive effect on in-store channel selection. We can assume that the household size will likely increase with the increase of the persons' age that explaining the pro-store orientation in the case of the "age" and "household size". However, the studies made by Lian and Yen [59], Maat and Konings [64], Hood et al. [65] emphasize that aged end-consumers make online shopping more likely than young adults. Besides that, Hood et al. [65] revealed that senior people are likely to shop online with the home delivery option than young people do. In this case, the age group 
of the shoppers correlates with occupation, such as "student", which contains young adults. So, based on literature review, this occupation status was revealed with contradictory effects in regard to shopping channel choice. Thus, the study by Farag et al. [54], which covered the USA and Netherlands residents, stated that students are less intent on buying online, especially in the USA. In turn, Comi and Nuzzolo [60] have assessed the purchase channel choice by end-consumers for a list of goods, namely: clothing, electronics, hygiene, and household products. The occupation "student" was considered as the economic dummy variable. Based on random utility modeling, the authors obtained contradictory results for the "student" factor. Thus, the young adults referred to as the "student" group for the clothing commodity were revealed as pro-online shoppers. Nevertheless, at the same time, this economic group was identified as in-store oriented regarding electronics purchases.

Based on the literature review, we can assume that given the differences in years between mentioned above studies, the shopping behavior of young adults has transformed from store-oriented to online-oriented. Hence, the pandemic situation could significantly contribute to this tendency. Moreover, this effect should be studied with differentiation on developed and developing economies that should provide insights into post-COVID-19 trends for shopping behavior.

\section{Methodology and Data}

\subsection{Survey Concept}

The survey is based on the concept that the COVID-19 pandemic has changed the purchase behavior of young adults in countries with developed and developing economies. Seventeen statements were formed and ordered on a five-point Likert scale for determining the consumers' perception of lockdown and pandemic crisis. The factor analysis is used to extract the latent factors reflecting the following issues. As the lockdown was deployed for the first time in the life of young adults, the first issue of the survey was to know how deep the crisis for them was and how strongly it affected their routine life and changed consumer habits. Given that, we aimed at extracting the factors that describe the common features of the perceived situation caused by the COVID-19 pandemic in developed and developing countries. Having the sample of $n$ young adults where each of them provided $P$ answers on formed statements, we can evaluate $k$ factors that form the loading matrix $L$. According to chosen five-point Likert scale metric, we can estimate the correlation between unobserved factors $\mathrm{F}$ and score $\mathrm{x}$ made by every young adult from the sample $n$. Hence, mathematically this can be described as follows [69]:

$$
z_{j i}=\sum_{p \in m} l_{j p} \cdot F_{p i}+\varepsilon_{j i}, j=1,2, \ldots, P ; i=1,2, \ldots, n
$$

where $z_{j i}$ is the normalized observed measurement; $l_{j i}$ is the factor loading; $F_{p i}$ is the factor; $\varepsilon_{j i}$ is the unobserved stochastic error term with mean zero and finite variance; $m$ is the number of common factors.

The normalization of $z_{j i}$ is made according to the instances of variable $x_{j}$ and its mean and standard deviation within the sample:

$$
z_{j i}=\left(x_{j i}-\mu_{j}\right) / \sigma_{j}
$$

where $\mu_{j}$ is the mean of $x_{j i}, \mu_{j}=\frac{1}{n} \cdot \sum_{i \in n} x_{j i}$; the standard deviation of $x_{j i}, \sigma_{j}=\sqrt{\frac{1}{n-1} \cdot\left(x_{j i}-\mu_{j}\right)^{2}}$.

It should be noted that a restriction on the minimum value for every loading should be implied. In this case, the number of the factors will be less than the observed variables (statements). Considering two alternative samples representing people with different sociodemographic data and personal beliefs, we assume that obtained factors could be unique concerning economy type. This assumption is complemented by the fact that the COVID19 crisis mainly started in developed countries such as Italy, the USA, and the UK [70], where people suffered a lot. Given that, the people from the countries with a low number of cases could perceive less danger even under lockdown conditions. Also, we should 
mention that e-commerce development is not the same between developed and developing countries. Hence, the change of shopping behavior can differ among the economies due to the attitudes of end-consumers towards online shopping and infrastructure development of the last-mile logistics to service e-purchases.

The main issue of this study that we aim to reveal is consumers' perception of the pandemic crisis from an economic point of view. There is a serious possibility that the pandemic crisis inclined people to cut down on money expenditures. In such conditions, we would like to reveal the rejected commodities by consumers during pandemic outbreaks and whether this list is as extensive as it is supposed to be. Moreover, in the face of a crisis, people could be scared of possible deficits in some goods or price rises that usually result in extra-shopping behavior [71]. We assume that a lockdown situation could incline people to buy more goods of first priority, medicine, and food. Also, the pandemic crisis could provoke compulsive behavior resulting in stockpiling of some goods [72].

Thus, the general hypothesis of this study is summarized in the conceptual framework presented in Figure 1. The logical composition is the following: COVID-19 forced governments around the globe to introduce and deploy lockdown measures. In such conditions, people changed their daily activity and behavior which has formed stress and deprivation. It is obvious that this would have affected shopping behavior forming two alternative purchase patterns: extra shopping and less shopping.

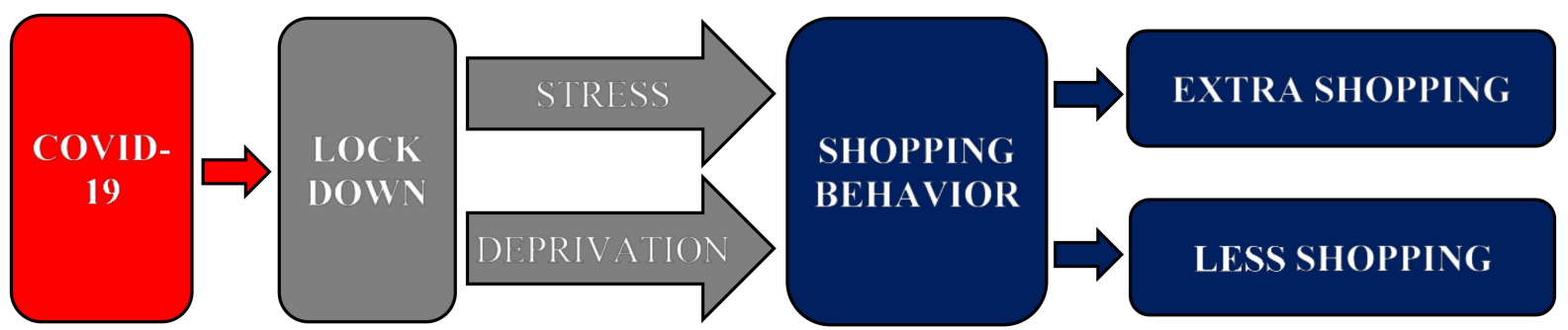

Figure 1. Conceptual framework of purchase behavior formation during COVID-19.

\subsection{Survey Description}

The survey is implemented through the polling of the respondents from developed and developing countries. The questionnaire was implemented in Google Form and disseminated via survey groups on Facebook to cover respondents from countries around the globe as much as possible. The questionnaire is structured as follows. The first section contains the questions on socio-demographic data of the respondents such as age, gender, country of residence, education, employment status before COVID-19, changes in employment status due to COVID-19, household size, number of cars in the household, number of employees in the household, personal monthly gross wage in EUR.

Within the second section, people were asked a list of questions for revealing purchase behaviors before and during the first wave of COVID-19. This study covers such commodities as food, medicine, the first priority goods (wipes, toilet paper, laundry detergent, and sanitizers), electronics, clothes, and shoes. At first, respondents had to point what purchase channel they used before and during the pandemic outbreak. The list of shopping channels is as follows: in-store, online-home delivery, online-pick up, or they could choose the option "do not buy this product". Only one choice was available to reflect the preferable shopping channel for every product from the list. People were asked whether they will keep purchasing the goods after COVID-19 in the same way they already used to during the pandemic. It allowed us to reveal the changes in used shopping channels. Along with shopping channel choice, this information allows us to assess the level of changes in shopping behavior caused by the pandemic. Within the second section, the respondents were asked about transport modes used for in-store/online shopping before and during COVID-19. This section ends with the questions about shopping frequency and average purchase costs (in EUR) for two periods. 
The third section is devoted to assessing 17 statements that provide data for the factor analysis described in the previous subsection. Guided by the studies Kitamura et al. [73], Mokhtarian et al. [74], Mokhtarian and Tang [75], we made some adaptations of used statements to the context of the pandemic crisis. So, the respondents were proposed to score these statements using a five-point Likert scale. As a result, we suppose to obtain data that reflect the latent roots of consumers' behavior during the pandemic. When the scoring of the statements is being made, the respondents reflect the level of perceived fear or calmness in the pandemic reality, awareness of their health during in-store shopping, inclination to buy more as usual products, or indicate no changes in purchase quantity.

\subsection{Samples}

The polling was started in April 2020 and finished at the beginning of July 2020 during the first wave of COVID-19. Given that the pandemic crisis was the first in the life of young adults, the unexpected scenarios of the pandemic gave us a unique opportunity to assess the perceived fear and danger in a new reality and how it influenced their shopping behavior. The survey's key point is the absence of information on the first stages about how long the pandemic will last.

Participation in the polling was voluntary without any payments from the research group side. During polling, we aimed at covering the same number of respondents from developed and developing countries, but the level of activity was much higher by the people from developed countries. Table 2 presents the quantitative sample characteristics of respondents concerning economy type. The countries in Table 2 were ordered according to the number of polling participants. The small number of observations per country (less than 10) was referred to as the category "Other". As the European region in the sample includes the countries of two types, the developed economy was pointed as "Other1a" and developing-as "Other $1 b$ ". The category "Other $2 c$ " contains countries from the Asia region. The total sample size is 632 respondents, where 515 people are from the developed, and 117 people represent developing countries. Table 3 provides the breakdown of the sample on socio-demographic characteristics.

Table 2. Sample description by countries.

\begin{tabular}{lllll}
\hline \multirow{2}{*}{ Region/Country } & \multicolumn{2}{c}{ Developed Economy } & \multicolumn{2}{l}{ Developing Economy } \\
\cline { 2 - 5 } & Units & $\%$ & Units & $\%$ \\
\hline Total number of respondents & 515 & 81.49 & 117 & 18.51 \\
North America & 78 & 100.00 & - & - \\
United States & 59 & 75.64 & - & - \\
Canada & 19 & 24.36 & - & - \\
Europe & 406 & 100.00 & 30 & 100.00 \\
United Kingdom & 181 & 44.58 & - & - \\
Netherlands & 62 & 15.27 & - & - \\
Germany & 51 & 12.56 & - & - \\
France & 31 & 7.64 & - & - \\
Italy & 23 & 5.67 & - & - \\
Poland & - & - & 17 & 56.67 \\
Portugal & 11 & 2.71 & - & - \\
Other1 & 47 (a) & 11.58 & 13 (b) & 43.33 \\
Australia & 31 & 100 & - & - \\
Asia & - & - & 87 & 100 \\
India & - & - & 29 & 33.34 \\
Malaysia & - & - & 28 & 32.18 \\
Other2 & - & - & 30 (c) & 34.48 \\
\hline
\end{tabular}

(a) Austria, Belgium, Denmark, Greece, Ireland, Latvia, Lithuania, Norway, Spain, Switzerland. (b) Bulgaria, Croatia, Malta, Moldova, North Macedonia, Romania. (c) Armenia, Bangladesh, Indonesia, Lebanon, Pakistan, Philippines, Russia, Singapore, Taiwan, Thailand, United Arab Emirates, Vietnam. 
Table 3. Breakdown of the sample.

\begin{tabular}{|c|c|c|c|c|}
\hline \multirow{2}{*}{ Socio-Demographic Attributes } & \multicolumn{2}{|c|}{ Developed Economy } & \multicolumn{2}{|c|}{ Developing Economy } \\
\hline & Units & $\%$ & Units & $\%$ \\
\hline Age & 515 & 100.00 & 117 & 100.00 \\
\hline $18-23$ & 214 & 41.56 & 51 & 43.59 \\
\hline $24-30$ & 219 & 42.52 & 47 & 40.17 \\
\hline $31-36$ & 82 & 15.92 & 19 & 16.24 \\
\hline Gender & 515 & 100.00 & 117 & 100.00 \\
\hline male & 151 & 29.32 & 41 & 35.04 \\
\hline female & 364 & 70.68 & 76 & 64.96 \\
\hline Education & 515 & 100.00 & 117 & 100.00 \\
\hline school & 64 & 12.43 & 25 & 21.37 \\
\hline bachelor's degree & 257 & 49.90 & 51 & 43.59 \\
\hline master's degree & 184 & 35.73 & 35 & 29.91 \\
\hline $\mathrm{PhD}$ & 10 & 1.94 & 6 & 5.13 \\
\hline Household size & 515 & 100.00 & 117 & 100.00 \\
\hline 1 & 82 & 15.92 & 13 & 11.11 \\
\hline 2 & 142 & 27.57 & 15 & 12.82 \\
\hline 3 & 112 & 21.75 & 21 & 17.95 \\
\hline 4 & 109 & 21.17 & 40 & 34.19 \\
\hline 5 and more & 70 & 13.59 & 28 & 23.93 \\
\hline Number of employees in household & 515 & 100.00 & 117 & 100.00 \\
\hline 1 & 224 & 43.50 & 41 & 35.04 \\
\hline 2 & 167 & 32.42 & 58 & 49.58 \\
\hline 3 & 68 & 13.20 & 13 & 11.11 \\
\hline 4 & 40 & 7.77 & 4 & 3.42 \\
\hline 5 and more & 16 & 3.11 & 1 & 0.85 \\
\hline Number of cars in household & 515 & 100.00 & 117 & 100.00 \\
\hline 0 & 128 & 24.85 & 18 & 15.38 \\
\hline 1 & 160 & 31.07 & 44 & 37.61 \\
\hline 2 & 133 & 25.83 & 30 & 25.64 \\
\hline 3 & 51 & 9.90 & 17 & 14.53 \\
\hline 4 and more & 43 & 8.35 & 8 & 6.84 \\
\hline Personal monthly gross wage & 515 & 100.00 & 117 & 100.00 \\
\hline No personal wage & 111 & 21.55 & 39 & 33.33 \\
\hline Low income & 259 & 50.29 & 27 & 23.08 \\
\hline Middle income & 77 & 14.96 & 31 & 26.50 \\
\hline High income & 68 & 13.20 & 20 & 17.09 \\
\hline
\end{tabular}

It should be noticed that a country has to fulfill a list of the specific criteria for considering it as a developed economy. Welfare is only one position from the list. Given that, additional control of the economy type is needed for the countries with high Gross Domestic Product such as Singapore, Taiwan, and the United Arab Emirates. Guided by the "Memorandum on Reforming Developing-Country Status in the World Trade Organization" [76], we referred the mentioned counties to the developing economies. The territory location problem can arise for the counties with a big area, such as Russia that located in both Europe and Asia. The vast territory of Russia is situated the Asia region, but its European part has a higher density of population. As we did not specify the city of residence for the respondents during the polling, we guided by the area criterion for Russia to refer this country to Asia. Another territory issue covered Armenia, which is situated on the edge between Europe and Asia. Given the fact that Armenia is located in the Armenian Highlands of Western Asia, we consider this country as Asian. 


\section{Results}

\subsection{Descriptive Analysis}

During polling, respondents were asked to assess preferences in purchase channels before and during the COVID-19 pandemic. The buying channels contained such options as in-store, online with home delivery, and online with pickup. Also, the respondent could point out some of the goods he/she did not purchase at all. That allowed us to evaluate how deep the pandemic affected end-consumers and their readiness to reject some goods. The results are presented in Figures 2 and 3, accordingly for developed and developing countries, which correlate with the findings of Mishkin [42] and Romer [44], i.e., people significantly reduce the costs of durable goods during the crisis. Thus, this effect was detected for both types of economy, but it is more pronounced for the developing one. Figure 3 indicates that $56.41 \%$ of young adults from developing countries did not buy electronics, and $39.32 \%$ of them reflected the same attitude toward clothing and shoes during COVID-19. For developed countries, the reduction in purchase activity for durable goods is quite substantial-47.96 and 35.53\%, accordingly, for electronics, clothing, and shoes. Given the polling was conducted for 3.5 months, which can be considered a short period for durable goods purchases, the above-made conclusion still stands. As spring is the period of sales, it is common for people to buy clothes and shoes to save money, especially for young adults. Nevertheless, during the survey period, we did not observe such behavior. This observation allows us to conclude money-saving behavior regarding durable goods.

Also, what should be noticed is the dramatic reduction of in-store-oriented consumers and shifting to online channel with home delivery option. This trend is observed for all studied commodities with more significant magnitudes for the developed economy. The preliminary findings on purchase channel choice have revealed a considerable shift from in-store purchases to online usage with home delivery. Our findings are supported by a World Trade Organization survey in e-commerce activity during COVID-19 [77]. We assume that this change was caused by the people's perceived risk of social contacts while visiting physical stores. The rejection of durable goods purchases during COVID-19 for both economies indicates the awareness of the financial risk that the pandemic could cause. This assumption will be checked more deeply in the next chapter based on factor analysis. Also, we would like to emphasize the medicine purchase behavior of young adults. Thus, for the developed economy, we defined a more substantial number of people that did not buy any medicine before and during COVID-19 compared with same-age people from developing countries. This finding correlates with the March 2020 survey made in the USA that revealed the readiness of people to suspend medicine purchases without vital necessity during the pandemic [78].

Along with the purchase channels usage, the polling is supposed to assess shopping frequency change due to COVID-19 and the lockdown deployment. The respondents were asked to indicate the usual purchase frequency before and during COVID-19. The assessment covered the buying process from frequent behavior (day-by-day buying) to purchases made once in two months or less. These data were evaluated in percentage change where the buying activity before the pandemic crisis has been considered the base. Figures 4 and 5 present the results for developed and developing economies.

As a result, we observed a reduction in purchase activity for such commodities as food, electronics, clothing, and shoes. Noticeable is the huge increase in percentage in food purchase frequency once in two months or less for both economies. This buying behavior was revealed as poorly distributed among end-consumers before the pandemic crisis. However, during the lockdown, some young adults from developed and developing countries changed their buying patterns to rarely frequent purchase activity, causing this category's significant growth. In addition, the analysis of frequency change complements the findings on purchase channels choice discussed early in this chapter. Specifically, Figures 4 and 5 reflect the significant increase in the frequency of "do not buy" for durable goods. The higher increase in this category for a developed economy is explained by the 
fact that before the pandemic, the number of people that did not buy, for instance, clothing and shoes, were more common in developing countries. Nevertheless, a general trend in money-saving is traced.

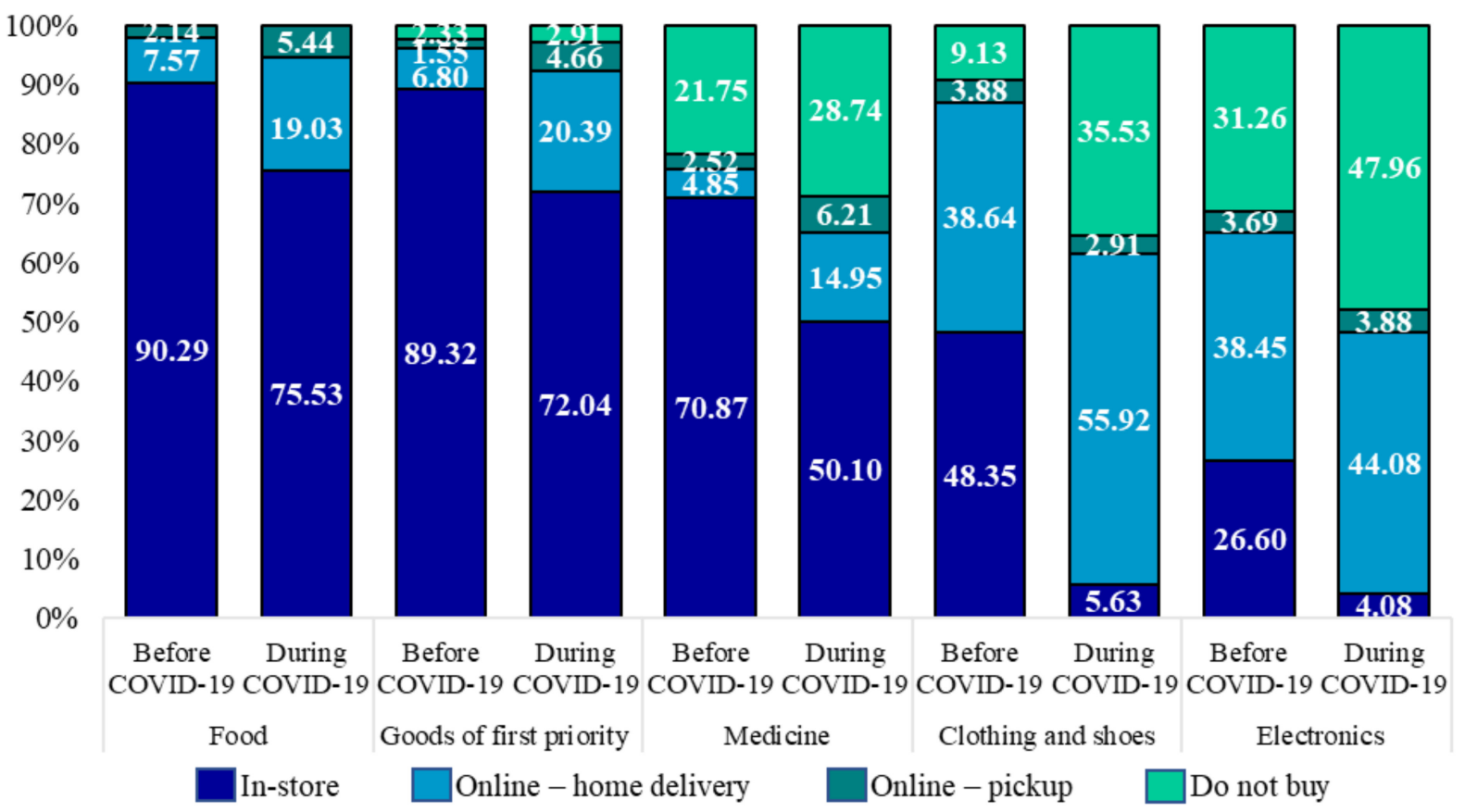

Figure 2. Purchase channel usage before and during COVID-19 in developed countries.

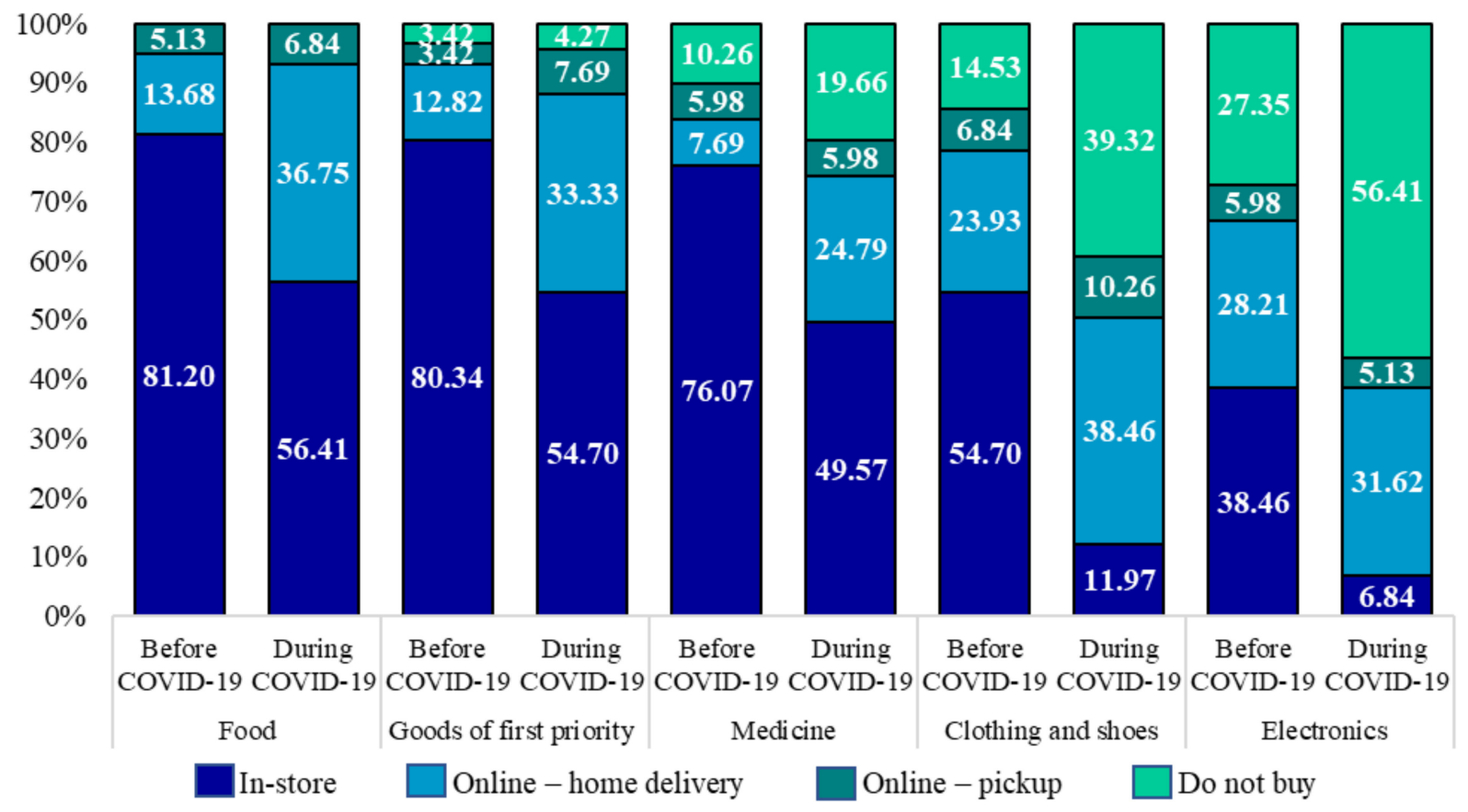

Figure 3. Purchase channel usage before and during COVID-19 in developing countries. 


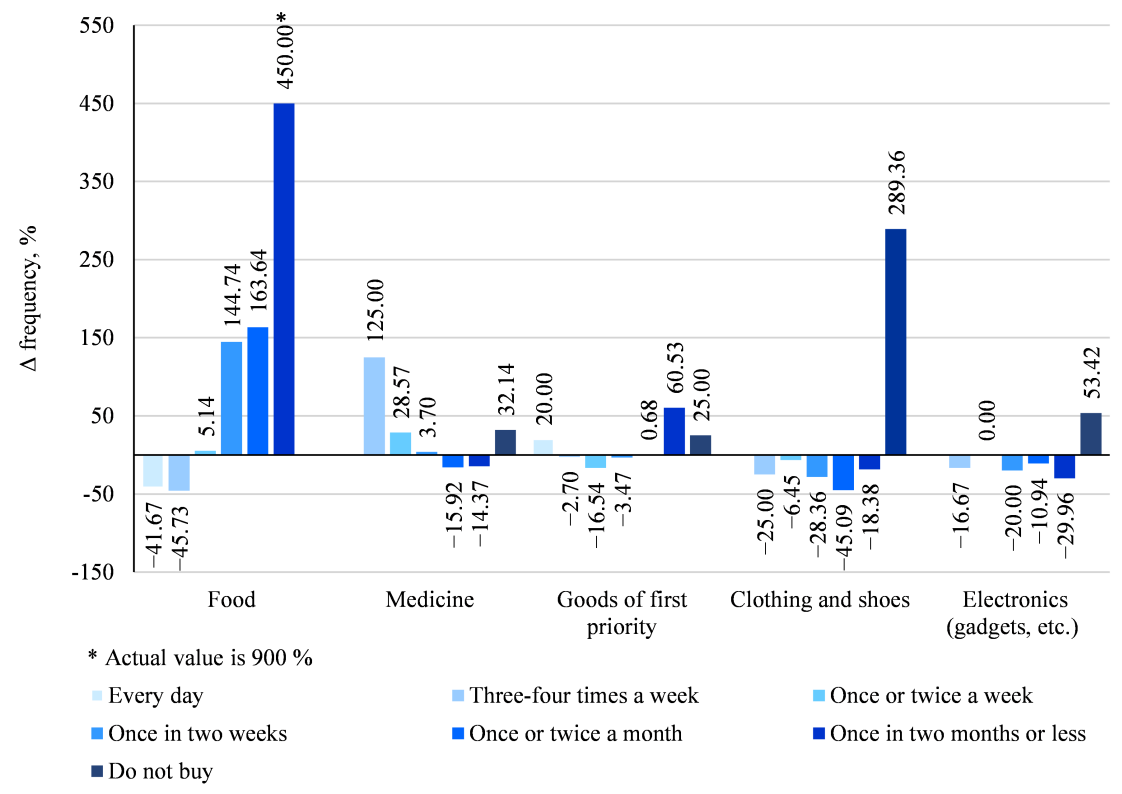

Figure 4. Purchase frequency change caused by COVID-19 in the developed countries.

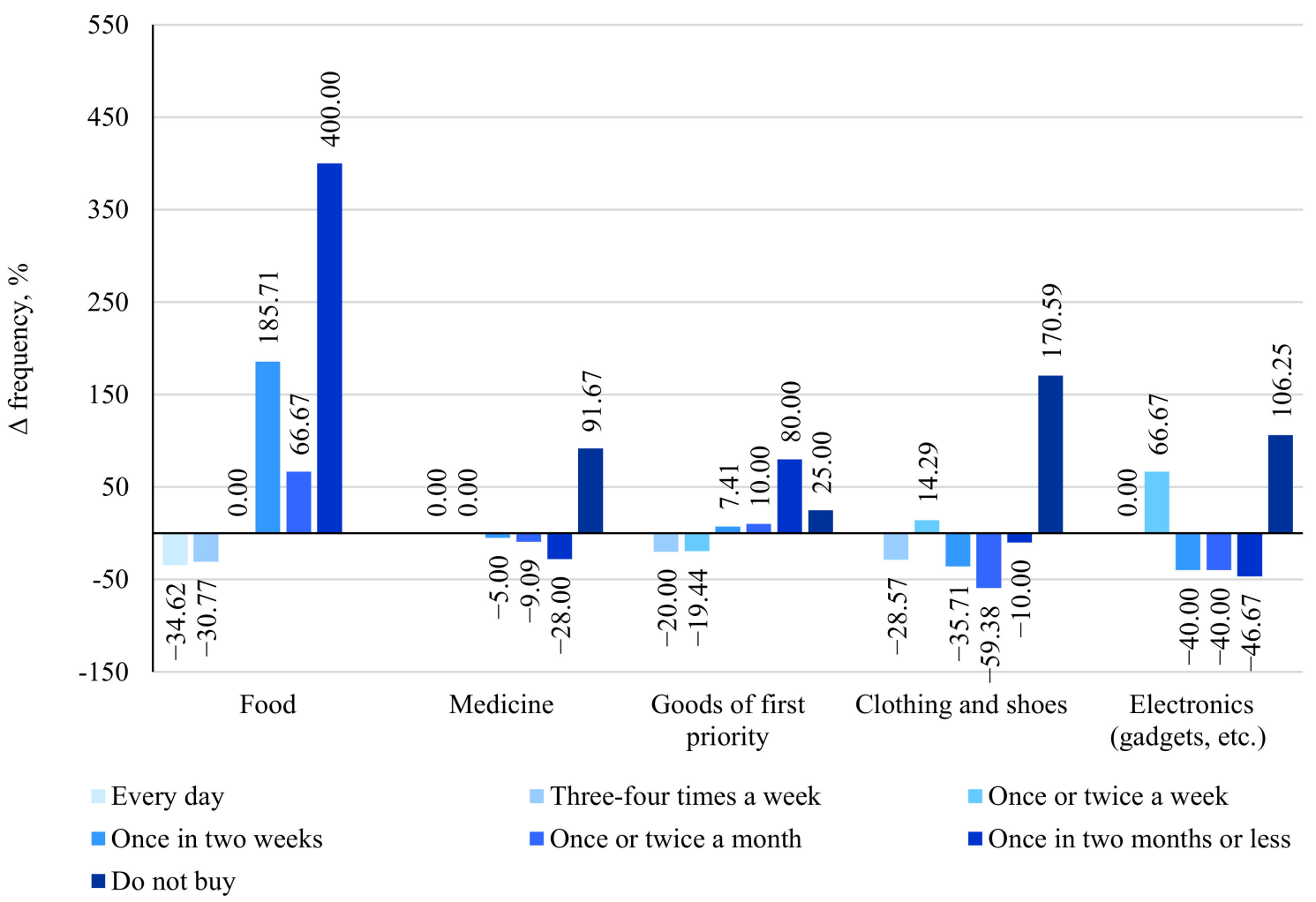

Figure 5. Purchase frequency change caused by COVID-19 in the developing countries.

The pandemic crisis could be thought of as a dangerous situation for the health and life of the people [79]. The rapid spread of the virus SARS-CoV-2 around the globe and the lockdown deployment should have affected the medicine purchase behavior. Figure 4 reveals a $128 \%$ increase in everyday frequency purchases for medicine, indicating the rapid growth in demand for goods of this category. We assume that the perceived fear and uncertainty caused this at the beginning of lockdown measures. However, people from developing countries pointed out that they did not change their purchase patterns significantly in medicine. This behavior can be explained by the fact that these people did 
not perceive the danger of the COVID-19 pandemic. Under this stage, such an explanation has a hypothetical shape. So, both assumptions will be evaluated in the next chapter using factor analysis methodology. Also, we would like to emphasize that the frequency of "do not buy" for medicine has grown too for the pandemic time, complementing the information from Figures 2 and 3.

Particular attention should be paid to the category "do not buy" in the case of purchase channel assessment (Figures 2 and 3) and frequency of buying (Figures 4 and 5). The analysis of such purchase patterns change from the prospect of socio-demographic data has shown that for the developed economy, the young adults with low income or "no income" formed $87 \%$ of people from the "do not buy" category within the pandemic time. For the developing economy, the picture is quite the same with an additional contribution to the "do not buy" category by the young adults with the middle income. As a result, the people with zero, low, and middle income have formed $84 \%$ of the entire specific weight that do not buy medicine during the pandemic crisis. Using this analysis, we may see that a money-saving problem has been perceived intensely in developing countries.

The commodity "goods of first priority" has shown an interesting picture for a developed economy: the slight increase (20\%) in everyday purchase activity and slight reduction for weekly buying activity. Only "once in a month or less" purchase activity has grown to $60.53 \%$. So, the purchase frequency of goods of first priority remained relatively stable during the pandemic crisis. However, for the developing countries, we have a little different picture with a slight reduction for high frequent purchase activity.

Human behavior during the crisis has economic roots [80]. The pandemic time of COVID-19 is not excluded. Purchase behavior, as was revealed in this chapter, has changed for both economies. We assume that it has been forced both by the external environment, such as market and demand conditions, and internal attributes reflecting people's economic readiness for the lockdown. This assumption is supported by the fundings of Cantillo et al. [81], showing that the level of deprivation reduces with an increase of the available budget of money at the disposal of a person.

In this study, we propose to assess the stability level of the young adults' economic state through the changes in employment status. Due to lockdown orders, the business changed its activity with an appropriate complex of implementation of measures. Some of these measures dealt with the change of job activity by transformation into a remote working process. Nevertheless, in some cases, especially for the service industry, the pandemic COVID-19 has become a real challenge. Thus, since March 2020, only in the USA a significant closure rate shown in shopping and retail (27,663 closed businesses), restaurants (23,981 closed businesses), and beauty (15,348 closed businesses), according to data provided by Yelp Economic Average (updated 25 June 2020) [82]. The young adults being involved in these businesses could have lost their jobs with an appropriate increase in their perception of the crisis struggle. Polling allowed us to reveal this process and assess the changes in employment status caused by the COVID-19 lockdown. Figure 6 presents the analysis results in this field for two economies.

As we can see, $9.32 \%$ of respondents from developed countries have lost their jobs. This relatively high rate is complemented by the data on employment status change being evaluated at $14.95 \%$. Thus, $24.27 \%$ of the young adults from developed countries have suffered due to income reduction or total loss. The picture for developing economy has some similarities, but with the softly negative impact of the pandemic. The reduction in personal income perceived $17.1 \%$ of respondents involved in the polling from developed countries. The changes in employment status affected people's behavior, forcing them to reduce their expenditures according to the rational choice theory $[83,84]$. Sometimes, during a crisis, people's behavior changes to addictive and panic manners, thus causing an extra shopping attitude [72]. Within this chapter, we propose to assess the availability of this behavior through the analysis of the purchase costs. The preliminary results show that the frequency of buying activity has been reduced (Figures 4 and 5). In this case, if we determine the increase in shopping costs, it will reflect a rise in buying of amounts of goods. 
In turn, it will mean the presence of addictive or panic shapes of the purchase behavior. Table 4 contains the data on purchase costs before and during the COVID-19 lockdown for two economy types regarding a list of commodities.

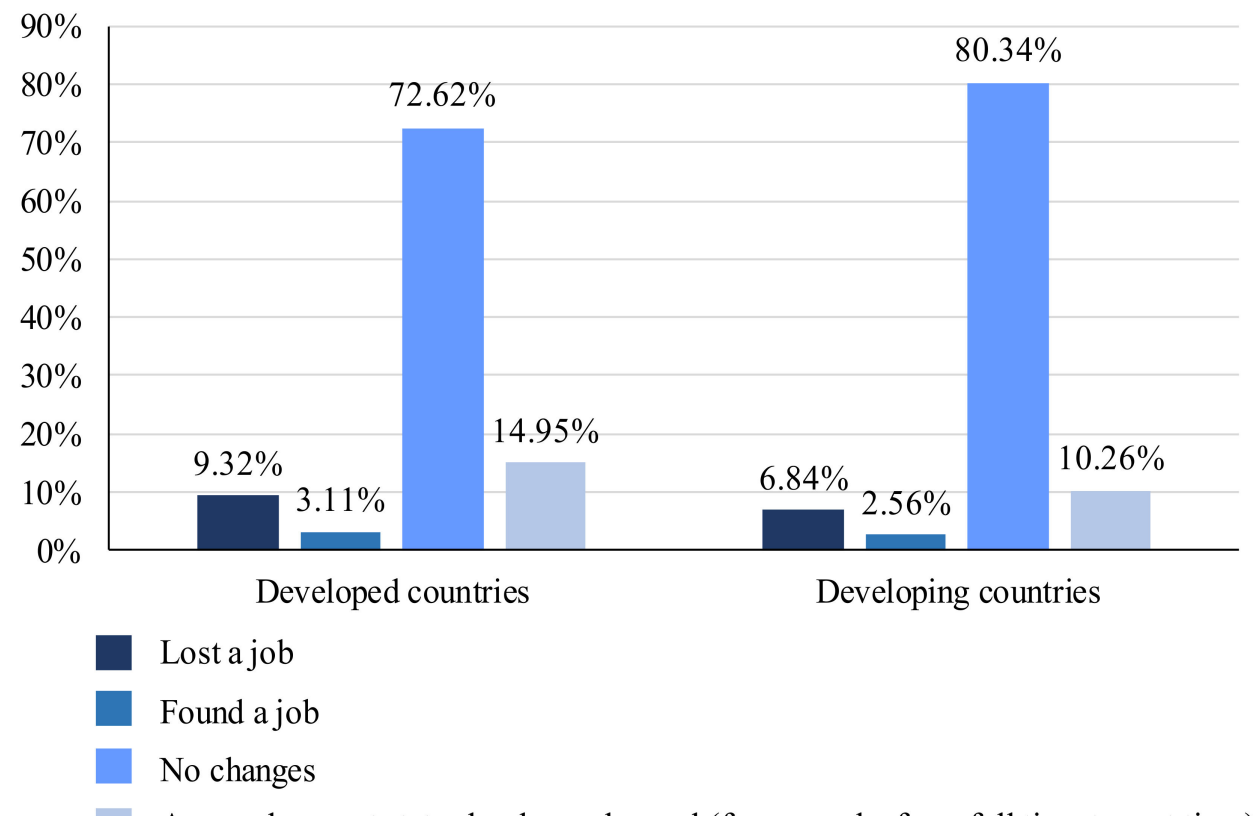

An employment status has been changed (for example, from full time to part time)

Figure 6. Occupation status change during the COVID-19 pandemic.

Table 4. Average check for a list of goods before and during COVID-19.

\begin{tabular}{|c|c|c|c|c|c|c|c|c|c|c|}
\hline \multirow{4}{*}{ Commodity } & \multicolumn{8}{|c|}{ The Average Check for One Purchase, EUR } & \multicolumn{2}{|c|}{ Change in Mean, Units/(\%) } \\
\hline & \multicolumn{4}{|c|}{ Developed Economy } & \multicolumn{4}{|c|}{ Developing Economy } & \multirow{3}{*}{$\begin{array}{l}\text { Developed } \\
\text { Economy }\end{array}$} & \multirow{3}{*}{$\begin{array}{l}\text { Developing } \\
\text { Economy }\end{array}$} \\
\hline & \multicolumn{2}{|c|}{$\begin{array}{l}\text { Before } \\
\text { COVID-19 }\end{array}$} & \multicolumn{2}{|c|}{$\begin{array}{l}\text { During } \\
\text { COVID-19 }\end{array}$} & \multicolumn{2}{|c|}{$\begin{array}{l}\text { Before } \\
\text { COVID-19 }\end{array}$} & \multicolumn{2}{|c|}{$\begin{array}{l}\text { During } \\
\text { COVID-19 }\end{array}$} & & \\
\hline & Mean & SD & Mean & SD & Mean & SD & Mean & SD & & \\
\hline Food & 74.86 & 80.02 & 97.68 & 99.13 & 51.88 & 68.57 & 58.50 & 71.59 & $22.82 /(30.48)$ & $6.62 /(12.77)$ \\
\hline Medicine & 22.30 & 25.62 & 31.04 & 64.46 & 22.48 & 13.11 & 25.80 & 15.66 & $8.74 /(39.20)$ & $3.32 /(14.78)$ \\
\hline First priority goods * & 30.21 & 34.95 & 37.32 & 43.48 & 26.59 & 17.58 & 33.13 & 26.58 & $7.11 /(23.54)$ & $6.53 /(24.56)$ \\
\hline Clothing and shoes & 87.78 & 78.39 & 86.72 & 82.68 & 69.20 & 108.02 & 66.48 & 122.36 & $-1.06(-1.21)$ & $-2.72(-3.93)$ \\
\hline Electronics (gadgets, etc.) & 152.29 & 178.22 & 131.77 & 171.72 & 133.41 & 179.03 & 122.25 & 214.05 & $-20.52(-3.47)$ & $-11.16(-8.36)$ \\
\hline
\end{tabular}

* wipes, toilet paper, laundry detergent, sanitizer, etc.

The summarized data in Table 4 indicates the increase in purchase costs (in raw percentage from 22 to 39) for food, medicine, and goods of first priority in the developed countries. The rise of average check value and the reduction in buying frequency allows us to conclude the increase in the number of goods purchased by young adults in developed countries during the pandemic crisis. The people from the developing countries show the highest change in average check value for goods of first priority ( $24.56 \%$ growth). The food and medicine also have been revealed with a slight increase in purchase costs, accordingly 12.77 and $14.78 \%$. So, the increase in purchase costs indicates the presence of extra shopping behavior for both economies. It might be forced by the inventory purpose in case of a possible deficit in the future. Under such conditions, we have a rational pro-shopping pattern.

Nevertheless, we do not have to exclude the possibility of the panic nature of the buying process [72] caused by COVID-19. It is especially true at the first stages of the lockdown when the panic purchases are at the development stage with the cumulative growth effect [85]. The nature of the extra-shopping attitude will be evaluated using factor analysis in the next chapter. 
The pandemic crisis has negatively influenced mobility. The lockdown with a stayat-home order, introduced in many developed and developing countries, substantially changed the mobility patterns with the mode choice option. In this study, we focused on assessing the mobility change in the case of in-store shopping trips. Figure 7 presents the specific weights for six alternative trip modes with additional conditions when the people do not attend the physical stores for shopping purposes. The trip patterns' comparison before and during COVID-19 in developed countries allowed us to determine a significant reduction in public transit usage from 17 to $3 \%$ among the respondents. The people shifted to private cars (change in users' number from 48 to 50\%), walking (an increase from 21 to $24 \%$ ), and biking (the slight increase from 6 to $7 \%$ ). So, we observe the social distancing intentions with a shift on isolated trip modes. This finding supports the survey results by Molloy et al. [3], Pepe [86], Tirachini and Cats [87], reflecting the total decrease in trips made by people during the COVID-19 pandemic.

$$
\begin{array}{lllllllllll}
0 \% & 10 \% & 20 \% & 30 \% & 40 \% & 50 \% & 60 \% & 70 \% & 80 \% & 90 \% & 100 \%
\end{array}
$$

Developed countries before COVID-19

Developed countries during COVID-19

Developing countries before COVID-19

Developing countries during COVID-19

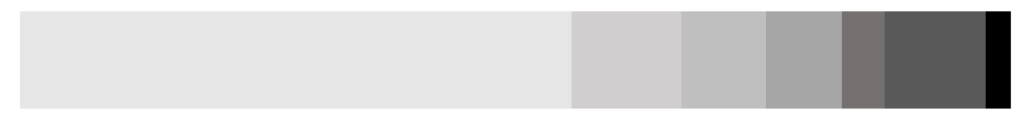

$$
\text { - own car - walking } \square \text { - transit } \square \text { - bike } \square \text { - bicycle } \square \underset{\begin{array}{l}
\text { - no purchase in-store } \\
\text { or/and online (with } \\
\text { pickup option) }
\end{array}}{\text { - carpooling }} \text { (carsharing) }
$$

Figure 7. Transport usage for in-store purchase before and during COVID-19.

To avoid unwanted social contacts during the pandemic crisis, some young adults from developed and developing countries did not attend physical stores at all. Thus, the number of such people increased from 2 to $8 \%$ for the developed economy, from 6 to $10 \%$ for the developing economy. Moreover, for developing countries, the compensation of reduction in public transit shopping trips has been made by increasing green modes usage such as walking and bicycling (one percent increase for each mode) and non-green bike mode (one percent of usages growth). The number of public transit users has also changed, but it is not so great as observed for the developed economy (reduced from 15 to $9 \%$ ). It seems that in developing countries the public transit usage is not perceived with as great a danger as in developed ones.

Also, it is noticeable that the developing economy has a more significant number of young adults that shifted to online shopping with home delivery by pointing to the choice "not purchase in-store or/and online with pickup option". The roots of this phenomenon will be studied in the next chapter. 


\subsection{Factor Analysis}

This chapter presents the factor analysis results to estimate the latent intentions and motivators for purchase behavior during the COVID-19 pandemic. The data for factor analysis were collected within the polling by 17 statements evaluation based on a five-point Likert scale. The factor analysis has been implemented with STATISTICA 7.0. Within the first step, we defined the eigenvalues for every one of 17 potential factors (presented in Figures 8 and 9 for both economies). According to the Kaiser criterion [88], we excluded all factors from the analysis that had eigenvalues less than 1.0. These levels for developed and developing economies are indicated with red dash lines in Figures 8 and 9. Varimax rotation was used to define the loadings and extract the factors. The lowest limit for the factor loading was fixed at 0.4 . As a result, four and five factors were revealed, accordingly, for developed and developing economies. The variances explained by the factors for the developed economy are 4.255, 1.734, 1.386 and 1.325, accordingly, for four extracted factors. In turn, the developing economy's factors have the following variances explained: 3.58 , $2.065,1.826,1.529,1.346$. The factors' loadings are shown in Table 5.

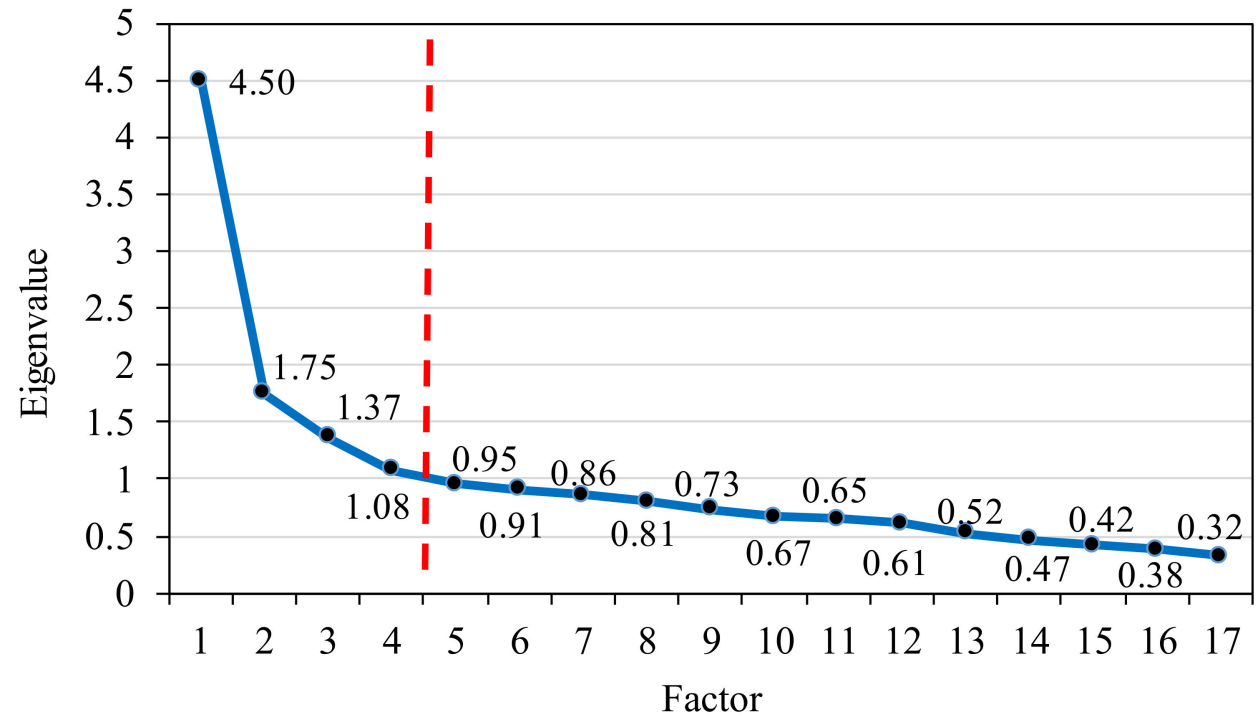

Figure 8. Eigenvalues according to the factor analysis for developed economy.

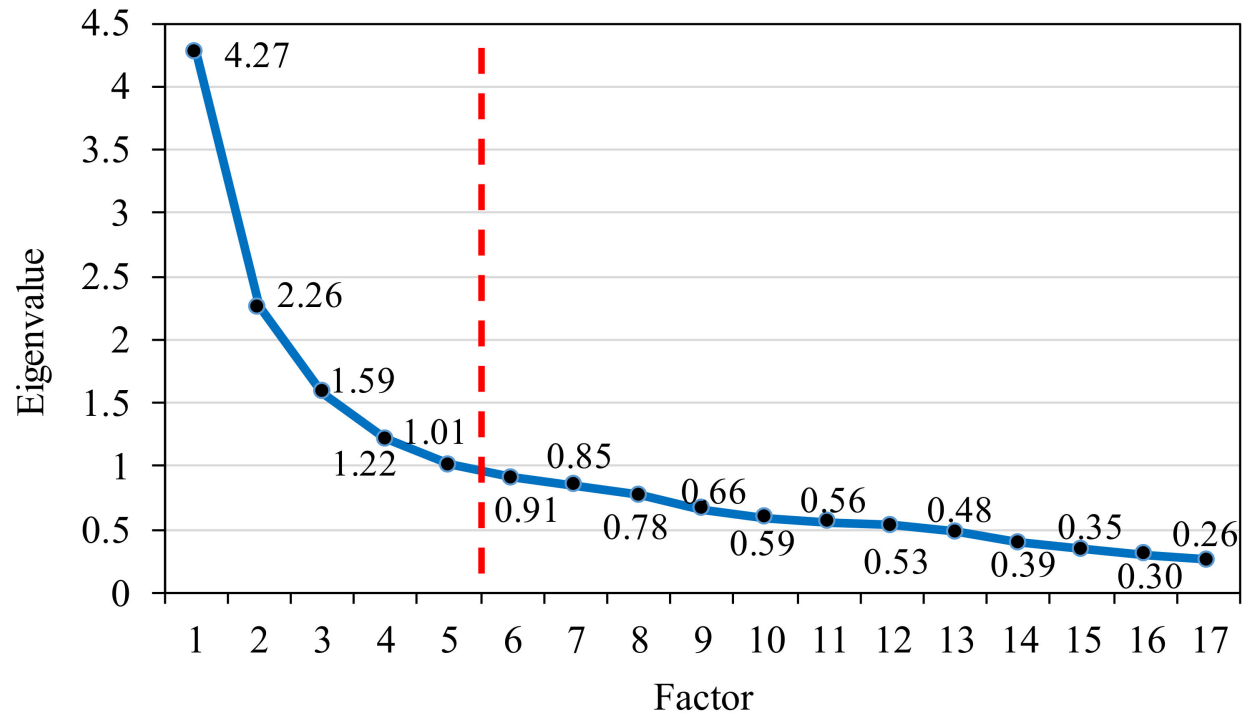

Figure 9. Eigenvalues according to the factor analysis for developing economy. 
Table 5. Factor analysis results regarding to the economy type.

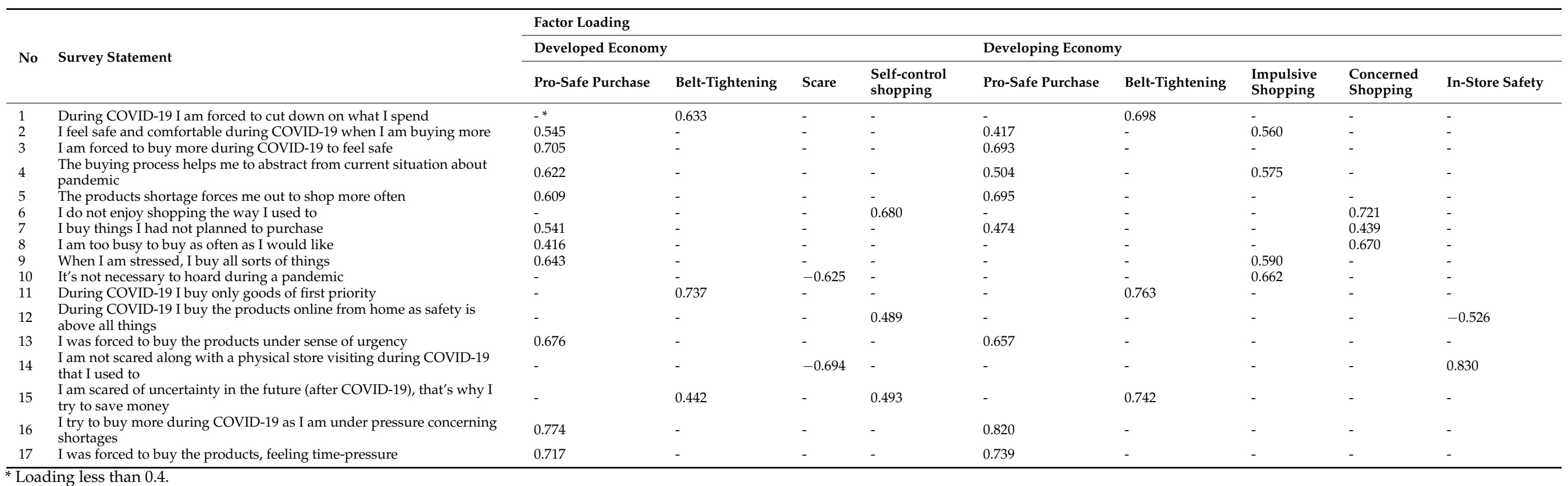


The factors were characterized as follows for the developed economy: "Pro-safe purchase", "Belt-tightening", "Scare", and "Self-control shopping". The developing economy factors were qualified as "Pro-safe purchase", "Belt-tightening", "Impulsive shopping", "Concerned shopping", and "In-store safety". We observed some similarities in the latent intentions of the buyers for both economies, such as "Pro-safe purchase" and "Belt-tightening". Nevertheless, other factors reflect quite different purchase behavior during COVID-19 in regard to economy type. Table 6 contains the explanations for all formalized factors.

Table 6. Factors description.

\begin{tabular}{|c|c|c|}
\hline Factor & Economy Type & Description \\
\hline Pro-safe purchase & $\begin{array}{l}\text { Developed, } \\
\text { Developing }\end{array}$ & $\begin{array}{l}\text { The physical safety of people was revealed as a valuable factor for both economies. It was reflected by the "Pro-safe } \\
\text { purchase" factor meaning the purchases for stock purposes. It should be pointed that the safety-oriented statements } \\
\text { have more significant loadings for the developed countries. We interpret this to mean that young adults from } \\
\text { developed countries perceived a higher level of the personal risk during the first wave of COVID-19 than developing } \\
\text { countries' residents. The purchase of goods for personal safety was of high value and gave the possibility to reduce } \\
\text { the risk and stress caused by the pandemic. }\end{array}$ \\
\hline Belt-tightening & $\begin{array}{l}\text { Developed, } \\
\text { Developing }\end{array}$ & $\begin{array}{l}\text { The uncertainty about the duration of the pandemic and its impact on economy forced people to cut down costs. It } \\
\text { complements the studies on the Great Depression [42,43] and the recession of the 2000th [45] and prove that } \\
\text { COVID- } 19 \text { should be referred to as a crisis state. The effect of "Belt-tightening" is pronounced more for the people } \\
\text { from developing countries. According to statistics data, we suppose this is caused by the high correlation with the } \\
\text { households' low income for the developing economy (Table } 3 \text { ). In this case, the deprivation level should be higher for } \\
\text { the developing economy, and the loading values support this assumption. }\end{array}$ \\
\hline Scare & Developed & $\begin{array}{l}\text { It is well known now that social contacts must be restricted to prevent the spread of the COVID-19 pandemic [79]. } \\
\text { According to the loading for the statement "I am not scared along with a physical store visiting during COVID-19 that } \\
\text { I used to", consumers from developed countries perceived a high level of fear and awareness about physical contacts } \\
\text { In such conditions, people tried to reduce their in-store shopping activity by buying in more quantity products. This } \\
\text { assumption is confirmed with the second loading for factor "Scare" "It's not necessary to hoard during a pandemic", } \\
\text { which was obtained with a negative value. Also, people could shift to online shopping to minimize their physical } \\
\text { interaction with other consumers. This assumption is supported by the revealed factor "Self-control shopping" that is } \\
\text { described below. }\end{array}$ \\
\hline Self-control shopping & Developed & $\begin{array}{l}\text { The pandemic crisis changed people's attitudes toward the shopping process. The enjoyment during physical store } \\
\text { visiting was reduced significantly due to self-control necessity. We state this according to the loadings obtained for } \\
\text { statements "I do not enjoy shopping the way I used to", "I am scared of uncertainty in the future (after COVID-19), that's why } \\
\text { I try to save money", and "During COVID-19 I buy the products online from home as safety is above all things". So, the } \\
\text { pleasure, the emotional feature of the shopping, was substituted with the control, planning, and safety intentions that } \\
\text { reflect the rational and self-control behavior. This factor complements the "Belt-tightening" factor with emphasis on } \\
\text { purchase channel shift to online inline. In this case, we can state that the online channel was chosen voluntarily by the } \\
\text { end-consumers. We cannot say that they were forced to do this because of some physical stores closure. }\end{array}$ \\
\hline Impulsive shopping & Developing & $\begin{array}{l}\text { For some people from developing countries, the purchase process was considered a way to escape the pandemic crisis } \\
\text { and perceived stress. The marked factor "Impulsive shopping" describes the purchase pattern that contradicts rational } \\
\text { behavior during the crisis when people should save money. We explain this with perceived inconveniences caused by } \\
\text { the lockdown and emergence of extra shopping behavior among people from the developing countries. We can } \\
\text { assume that buying process during the pandemic gave people from the developing countries perception of "usual life" } \\
\text { and safety. }\end{array}$ \\
\hline Concerned shopping & Developing & $\begin{array}{l}\text { Factor "Concerned shopping" reflects the negative aftermath caused by the pandemic. First of all, people did not } \\
\text { perceive any joy during the shopping process. However, opposed to the developed economy where people had a high } \\
\text { level of perceived fear and scare (presented with factors "Scare" and "Self-control shopping") factor "Concerned } \\
\text { shopping" indicate a low level of danger. This is confirmed with the factor "In-store safety" revealed for the } \\
\text { developing economy. It also should be noticed that factor "Concerned shopping" has some similarities with } \\
\text { "Self-control shopping" detected for the developed economy, but there is a difference between them. The restrictions } \\
\text { in mobility and stores access in the developing economy provoked discomfort and the necessity to buy goods not } \\
\text { planned. It is supported with the loading value determined for the statement "I am too busy to buy as often as I would } \\
\text { like". We see that online channel did not substitute in-store shopping as it was revealed for the developed economy. } \\
\text { Nevertheless, an increase in time expenditures for shopping due to safety protocols formed the concerned shopping } \\
\text { phenomenon. }\end{array}$ \\
\hline In-store safety & Developing & $\begin{array}{l}\text { The perceived danger attitude due to COVID-19 was revealed with the opposite effect in the context of developed and } \\
\text { developing economies. Thus, the respondents evaluated the statement "I am not scared along with a physical store } \\
\text { visiting during COVID-19 that I used to" with the highest positive loading value among all estimations for developing } \\
\text { economy. It reflects the minor worries about in-store shopping activity during the pandemic outbreaks in developing } \\
\text { countries. Complementing this, we obtained the negative loading value for the statement "During COVID-19 I buy the } \\
\text { products online from home as safety is above all things". It means people were not inclined to buy online during COVID-19 } \\
\text { as it is a safer option than physical store shopping. We consider this result an interesting finding revealing fewer } \\
\text { concerns about personal safety by the people in the developing countries than in the developed ones. Considering the } \\
\text { descriptive analysis results, we can conclude that the significant shift of people to online channel was not driven by } \\
\text { the scare and necessity for social distancing. This finding will be supported by statistical data on future people's } \\
\text { intentions on post-COVID-19 shopping channels discussed in the next chapter. }\end{array}$ \\
\hline
\end{tabular}

\section{Discussion}

\subsection{Key Findings}

Based on the obtained results of this study, we can distinguish the following findings:

- For both economies, we revealed the change in shopping behavior caused by the COVID-19 pandemic with strong online orientation in developed countries and a 
slight shift to online channel in developing economies. This effect is more pronounced for clothing/shoes and electronics that can be explained with store closure.

- The reduction of shopping frequency revealed more significant values in developed countries. Young adults' rejection of buying electronics (durable goods) is revealed as a common feature for both economies. This finding confirms the study by Mishkin [42], Mian and Sufi [45] that covered the Great Depression and recession of the 2000th. Based on that, we can state that the COVID-19 pandemic has similar features to the economic crisis and provoked significant changes in consumers' behavior.

- Along with shopping frequency reduction, we revealed the increase in average check values. Food products have the highest level of shopping expenditures increase within the commodities assessed for the developed economy. First priority goods were the main target of young adults in the developing economy with slightly less demand for foods. Comparing the two economies, we can state that young adults spent more money on food, medicine, and first priority goods than those of this age in developing countries. However, considering the difference in currencies, we can conclude that money expenditures on first priority goods were higher in developing economies in the light of household budgets.

- Comparing mode choice behavior in pre-pandemic and during COVID-19 times confirmed young adults' concerns about necessity in social distancing for safety. Private cars and walking became preferable modes for shopping trips by young adults for both economies. In turn, the city transit significantly rejected for purchase commuting. This effect is pronounced more for the developed economy.

- Based on factor analysis, we revealed the common factors as "Pro-safe purchase" and "Belt-tightening" for both economies, reflecting the young adults' awareness about safety that inclined people to purchase for stock purposes. Young people were inclined to cut their expenditures as some of them have lost their job or the employment status changed negatively (see Figure 6). Along with that, young adults from developed countries perceived a higher level of fear and danger, which was confirmed by the extracted factors as "Scare" and "Self-control shopping". They revealed a strong intention to reduce social contacts and shift to online shopping. As for the developing economy, we determined the fewer level of danger and fear perceived by young adults. They were not afraid to visit physical stores but without any pleasure from the shopping process caused by the deployed restriction for shops entrance. Also, young people from developing countries intended to impulsive shopping to level the stress.

- According to polling, we evaluated the possible changes in young adults' shopping behavior in post-COVID-19 time. Thus, Figure 10 reflects the percentage of adults' readiness to return to pre-pandemic purchase channels. We can say that the intention to return to pre-COVID-19 purchase behavior is quite firm (76.89\% of people want to use accustomed purchase channels). As for the developing economy, according to obtained results, we can state that the increase in online channel users can be characterized as a voluntary choice by young adults. It forms a massive opportunity for e-commerce deployment in post-COVID-19 time in developing countries. Thus, a raw $36 \%$ of young adults that shifted to online channel with home delivery options are ready to use this service in the post-pandemic time.

\subsection{Policy Implications}

The pandemic crisis has significantly changed the shopping behavior of young adults in both developed and developing countries. Despite a slightly less danger and fear perceived by young adults in the developing economy, the changes in shopping channel choices and purchase frequency, quantity, and goods preferences formed extensive pressure on last-mile logistics for both economies. Due to the rapid increase for online orders with home delivery options, the last-mile logistics reached the limits for carrying capacities very fast during the first wave of the pandemic. For instance, Walmart Online Grocery service 
in the USA got its limits in March-April 2020 due to high demand for home delivery [89]. Given that, the study's results allow us to summarize the following implications:

- The rapid rise of the demand for e-groceries in the developed economies was inclined first of by the fear and safety concerns perceived by the young adults. But most people are ready to return to in-store shopping in post-COVID-19 times which is confirmed by this study results complementing other studies in this field for developed economies [90]. In this case, the emphasis of the supply chain and retail systems on online channel usage in post-COVID-19 times could cause the disbalance in the supply system due to consumers returning to in-store shopping. As for the developing countries, the e-commerce sector got a new level of the development as the onlineoriented behavior of young adults was significantly less shaped with health concerns and perceived danger from in-store shopping. Given that, they are likely to use ecommerce in post-pandemic times. Lack of carrying capacities of the last-mile delivery system due to high demand for home deliveries should be eliminated by providing crowdsourcing-based technologies [91]. Thus, crowd-shipping allows the supply system in a brief period to react to the rapid rise in demand for home deliveries without any financial investments and risks accompanying them. Moreover, the last-mile system will be more flexible under such conditions than when commercial transport is used.

- To reduce the level of concerns caused by the restriction to the physical shops, the opening hours for grocery stores should be extended. The best option is to provision $24 \mathrm{~h}$ access for in-store purchases to allow people to schedule their shopping activity during the pandemic crisis. Given the factor analysis results, this issue is crucial for developing countries where the e-grocery option is not well developed.

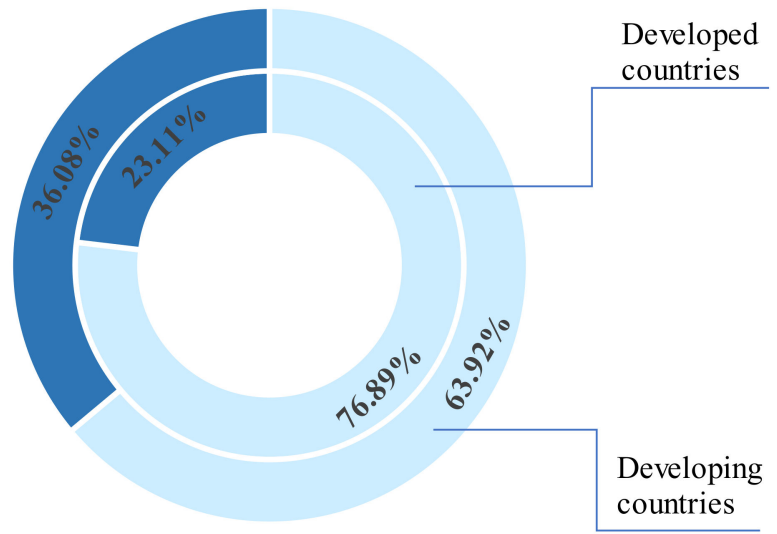

Return to original purchase channel after the end of COVID-19

No return to original purchase channel after the end of COVID-19

Figure 10. Breakdown of the sample according to stated post COVID-19 purchase behavior.

\subsection{Study's Limitations}

Despite a great effort made to cover as much as we can number of young adults around the globe to reveal their shopping behavior change during the first wave of COVID-19, we should point that formed samples are not equivalent. The formed samples for both economies are not equal, which provides constraints for obtained results. So, the first issue that should be mentioned is the low number of young adults that present developing countries. Given the exploratory feature of this study, we used both samples for descriptive and factor analyses, but it should be mentioned that under increasing the number of the observations for developing economy the factor analysis results would be more confident. Also, we should point the reader's attention to the fact that the sample for developing economy includes the countries with high GDP, such as Taiwan, Singapore, the United Arab Emirates, etc. Given that, some biases could be formed as, for instance, we obtained 
almost equal private car availability in the households for both samples (Table 3). Hence, the revealed differences in the shopping behavior of the consumers in the considered economies could be more significant.

The second issue is the absence of Chinese people in the sample for developing economy. Unfortunately, young adults from China could not participate in the polling as this country's chosen channel for questionnaire dissemination was not allowed. Given the restrictions for international social networks in China, Chinese young adults' essential information about shopping behavior change could not be collected. Without a doubt, this would be a significant contribution to factor analysis results as the lockdown measures in some parts of the country were very severe, and people were firmly obligated to carry out all requirements. Along with the rapid growth of the first cases of COVID-19 in Hubei Province, it is evident that the shopping behavior of Chines young adults changed considerably.

\section{Conclusions}

This paper reveals the roots of changes in the purchase behavior of young adults in developed and developing countries caused by the outbreak of the COVID-19 pandemic in spring 2020. The purchase behavior dataset for five commodities has been formed through a polling process and covered 515 respondents from developed and 117 from developing countries. The polling core for developed economies is formed by respondents from the USA, the United Kingdom, the Netherlands, and Germany. Young adults from India and Malaysia primarily represent the developing economies in the second sample. The conducted analysis of before and during COVID-19 purchase behavior has determined the significant changes of the consumers' behavior for developing and developed economies. We have estimated the substantial shift in purchase channel from in-store to online shopping with home delivery option for all five goods and two types of the economy. Food, clothing, and shoes were revealed with the most considerable percentages of new customers for home delivery services. Online-oriented shopping behavior was substantial for developing countries, especially for food (23.07\% growth of new customers) and goods of first priority (20.51\% growth of new customers), showing the rapid development of e-commerce due to COVID-19. According to the literature review, it was determined that people's behavior could produce the "less shopping" and "extra shopping" purchase patterns within the economic crisis. This survey's findings have proved the emergence of these behaviors due to the pandemic crisis. These purchase intentions have been revealed using the factor analysis based on a five-point Likert scale for 17 statements assessment.

Thus, for the developed economies, we defined four factors as "Pro-safe purchase", "Belt-tightening", "Scare", and "Self-control shopping". In general, all these factors describe the necessity of costs restriction by young adults and perceived negative emotions due to COVID-19. The necessity to reduce some activities, such as physical store shopping, also has been detected. The respondents have expressed concern and even fear because of the pandemic that forced them to reject durable goods purchases and restrict the frequency of the shopping process. At the same time, we estimated the increase of average purchase check for food $(+30.48 \%)$, medicine $(+39.20 \%)$, and goods of first priority $(+23.54 \%)$, contributing to extra shopping patterns. Most respondents have revealed a solid intention to buy goods online with a home delivery option as the safer purchase channel compared with in-store shopping. Complementing this, we defined the changes in shopping mode choice with a high level of rejection in public transit usage. The determined purchase patterns during the pandemic crisis for the developed countries are similar to people's behavior under economic crisis, for example, during the Great Depression and the economic crisis of 2008.

The purchase behavior during COVID-19 in the developing economies has been determined with other shapes than for developed ones. The factor analysis resulted in five factors as "Pro-safe purchase", "Belt-tightening", "Impulsive shopping", "Concerned shopping", and "In-store safety". The first two factors describe the same attitude to 
the pandemic crisis as in the developed economies. The young adults have shown the necessity of costs restriction during COVID-19. However, it is noticeable that we observe a more intense extra shopping behavior reflected by the factor "Shopping addiction" for the developing economies. Moreover, the change in purchase channel in favor of online shopping has been inclined with less stress and fear shapes. The raw $36 \%$ of young adults from the developing countries have expressed the positive intention not to return to in-store shopping in post-pandemic time. We conclude that the behavior changes towards online shopping channel has non-fear roots in developing economies. It is a positive indicator for the further development of e-commerce with the home delivery option in the developing countries in the post-COVID-19 time.

Author Contributions: Conceptualization, A.R.; methodology, A.R.; formal analysis, A.R., Y.A.; data curation, A.R.; writing-original draft preparation, A.R.; writing-review and editing, A.R., O.L.; visualization, A.R., Y.A.; supervision, A.R. All authors have read and agreed to the published version of the manuscript.

Funding: This research was supported by the Fulbright Program sponsored by the U.S. Department of State, Bureau of Educational and Cultural Affairs (ECA), Exchange Visitor Program \#G-1-00005 (Participant ID: PS00284928; Name: Alexander Rossolov).

Institutional Review Board Statement: Not applicable.

Informed Consent Statement: Informed consent was obtained from all subjects involved in the study.

Data Availability Statement: Due to privacy concerns, neither the data nor the source of the data can be made available.

Acknowledgments: The authors would like to acknowledge the Center for Infrastructure, Transportation, and the Environment at Rensselaer Polytechnic Institute for hosting the Fulbright Scholarship Program and five anonymous reviewers that provided valuable comments and suggestions for improving the manuscript.

Conflicts of Interest: The authors declare no conflict of interest.

\section{References}

1. Aloi, A.; Alonso, B.; Benavente, J.; Cordera, R.; Echániz, E.; González, F.; Ladisa, C.; Lezama-Romanelli, R.; López-Parra, Á.; Mazzei, V.; et al. Effects of the COVID-19 Lockdown on Urban Mobility: Empirical Evidence from the City of Santander (Spain). Sustainability 2020, 12, 3870. [CrossRef]

2. Beck, M.J.; Hensher, D.A. Insights into the impact of COVID-19 on household travel and activities in Australia-The early days under restrictions. Transp. Policy 2020, 96, 76-93. [CrossRef]

3. Molloy, J.; Tchervenkov, C.; Hintermann, B.; Axhausen, K.W. Tracing the Sars-CoV-2 Impact: The First Month in Switzerland. Transp. Find. 2020, 1503, 12903. [CrossRef]

4. Laato, S.; Islam, A.N.; Farooq, A.; Dhir, A. Unusual purchasing behavior during the early stages of the COVID-19 pandemic: The stimulus-organism-response approach. J. Retail. Consum. Serv. 2020, 57, 102224. [CrossRef]

5. Beckers, J.; Cárdenas, I.; Verhetsel, A. Identifying the geography of online shopping adoption in Belgium. J. Retail. Consum. Serv. 2018, 45, 33-41. [CrossRef]

6. Hall, M.C.; Prayag, G.; Fieger, P.; Dyason, D. Beyond panic buying: Consumption displacement and COVID-19. J. Serv. Manag. 2020, 32, 113-128. [CrossRef]

7. Rossolov, A.; Kuzkin, O.; Rossolova, H. Emergency supplies purchase patterns during COVID-19 outbreak in the developing economy: Frequency and stockpiling drivers' assessment. J. Humanit. Logist. Supply Chain Manag. 2021, 12, 106-128. [CrossRef]

8. Belzunegui-Eraso, A.; Erro-Garcés, A. Teleworking in the Context of the Covid-19 Crisis. Sustainability 2020, 12, 3662. [CrossRef]

9. Beck, M.J.; Hensher, D.A. Australia 6 months After COVID-19 Restrictions Part 2: The Impact of Working from Home. Transp. Policy 2021, in press. [CrossRef]

10. Jabbour, A.B.L.D.S.; Jabbour, C.J.C.; Hingley, M.; Vilalta-Perdomo, E.; Ramsden, G.; Twigg, D. Sustainability of supply chains in the wake of the coronavirus (COVID-19/SARS-CoV-2) pandemic: Lessons and trends. Mod. Supply Chain Res. Appl. 2020, 2, 117-122. [CrossRef]

11. Choi, T.-M. Innovative "Bring-Service-Near-Your-Home" operations under Corona-Virus (COVID-19/SARS-CoV-2) outbreak: Can logistics become the Messiah? Transp. Res. Part E Logist. Transp. Rev. 2020, 140, 101961. [CrossRef] [PubMed]

12. Ivanov, D. Viable supply chain model: Integrating agility, resilience and sustainability perspectives-lessons from and thinking beyond the COVID-19 pandemic. Ann. Oper. Res. 2020, 1-21. [CrossRef] 
13. Ducret, R. Parcel deliveries and urban logistics: Changes and challenges in the courier express and parcel sector in Europe-The French case. Res. Transp. Bus. Manag. 2014, 11, 15-22. [CrossRef]

14. Morganti, E.; Dablanc, L.; Fortin, F. Final deliveries for online shopping: The deployment of pickup point networks in urban and suburban areas. Res. Transp. Bus. Manag. 2014, 11, 23-31. [CrossRef]

15. Cárdenas, I.; Beckers, J.; Vanelslander, T. E-commerce last-mile in Belgium: Developing an external cost delivery index. Res. Transp. Bus. Manag. 2017, 24, 123-129. [CrossRef]

16. Hagen, T.; Scheel-Kopeinig, S. Would customers be willing to use an alternative (chargeable) delivery concept for the last mile? Res. Transp. Bus. Manag. 2021, 39, 100626. [CrossRef]

17. Clemens, K.S.; Matkovic, J.; Faasse, K.; Geers, A.L. Determinants of safety-focused product purchasing in the United States at the beginning of the global COVID-19 pandemic. Saf. Sci. 2020, 130, 104894. [CrossRef]

18. Grashuis, J.; Skevas, T.; Segovia, M.S. Grocery Shopping Preferences During the COVID-19 Pandemic. Sustainability 2020, 12, 5369. [CrossRef]

19. Wang, E.; An, N.; Gao, Z.; Kiprop, E.; Geng, X. Consumer food stockpiling behavior and willingness to pay for food reserves in COVID-19. Food Secur. 2020, 12, 739-747. [CrossRef]

20. Beckers, J.; Weekx, S.; Beutels, P.; Verhetsel, A. COVID-19 and retail: The catalyst for e-commerce in Belgium? J. Retail. Consum. Serv. 2021, 62, 102645. [CrossRef]

21. Nguyen, M.H.; Armoogum, J.; Thi, B.N. Factors Affecting the Growth of E-Shopping over the COVID-19 Era in Hanoi, Vietnam. Sustainability 2021, 13, 9205. [CrossRef]

22. Laguna, L.; Fiszman, S.; Puerta, P.; Chaya, C.; Tárrega, A. The impact of COVID-19 lockdown on food priorities. Results from a preliminary study using social media and an online survey with Spanish consumers. Food Qual. Prefer. 2020, 86, 104028. [CrossRef] [PubMed]

23. Naeem, M. Understanding the customer psychology of impulse buying during COVID-19 pandemic: Implications for retailers. Int. J. Retail. Distrib. Manag. 2020, 49, 377-393. [CrossRef]

24. Xiao, H.; Zhang, Z.; Zhang, L. A diary study of impulsive buying during the COVID-19 pandemic. Curr. Psychol. 2020, 1-13. [CrossRef] [PubMed]

25. Jeżewska-Zychowicz, M.; Plichta, M.; Królak, M. Consumers' Fears Regarding Food Availability and Purchasing Behaviors during the COVID-19 Pandemic: The Importance of Trust and Perceived Stress. Nutrients 2020, 12, 2852. [CrossRef]

26. Koch, J.; Frommeyer, B.; Schewe, G. Online Shopping Motives during the COVID-19 Pandemic-Lessons from the Crisis. Sustainability 2020, 12, 10247. [CrossRef]

27. Moon, J.; Choe, Y.; Song, H. Determinants of Consumers' Online/Offline Shopping Behaviours during the COVID-19 Pandemic. Int. J. Environ. Res. Public Health 2021, 18, 1593. [CrossRef]

28. Breitbarth, E.; Gro $\beta$, W.; Zienau, A. Protecting vulnerable people during pandemics through home delivery of essential supplies: A distribution logistics model. J. Humanit. Logist. Supply Chain Manag. 2021, 11, 227-247. [CrossRef]

29. Sokat, K.Y.; Altay, N. Serving vulnerable populations under the threat of epidemics and pandemics. J. Humanit. Logist. Supply Chain Manag. 2021, 11, 176-197. [CrossRef]

30. Myers, D.G. The funds, friends, and faith of happy people. Am. Psychol. 2000, 55, 56-67. [CrossRef]

31. Schmid, B.; Axhausen, K.W. In-store or online shopping of search and experience goods: A hybrid choice approach. J. Choice Model. 2018, 31, 156-180. [CrossRef]

32. Rossolov, A.; Rossolova, H.; Holguín-Veras, J. Online and in-store purchase behavior: Shopping channel choice in a developing economy. Transportation 2021, 48, 3143-3179. [CrossRef]

33. Pratt, J.W. Risk Aversion in the Small and in the Large firm. Econometrica 1964, 32, 122-136. [CrossRef]

34. Bauer, R.A. Consumer behavior as risk taking. In Risk Taking and Information Handling in Consumer Behavior; Cox, D.F., Ed.; Harvard University Press: Cambridge, MA, USA, 1960; pp. 389-398.

35. Mitchell, V. Consumer perceived risk: Conceptualisations and models. Eur. J. Mark. 1999, 33, 163-195. [CrossRef]

36. Sweeney, J.C.; Soutar, G.; Johnson, L.W. The role of perceived risk in the quality-value relationship: A study in a retail environment. J. Retail. 1999, 75, 77-105. [CrossRef]

37. Baum, A. Toxins, Technology, and Natural Disasters, in Cataclysms, Crises and Catastrophes: Psychology in Action; Vanden Bos, G.R., Bryant, B.K., Eds.; American Psychological Association: Washington, DC, USA, 1987; pp. 5-53.

38. Freudenburg, W.R. Perceived Risk, Real Risk: Social Science and the Art of Probabilistic Risk Assessment. Science 1988, $242,44-49$. [CrossRef]

39. Rhodes, T. Risk environments and drug harms: A social science for harm reduction approach. Int. J. Drug Policy 2009, $20,193-201$. [CrossRef]

40. Holguín-Veras, J.; Taniguchi, E.; Jaller, M.; Aros-Vera, F.; Ferreira, F.; Thompson, R. The Tohoku disasters: Chief lessons concerning the post disaster humanitarian logistics response and policy implications. Transp. Res. Part A Policy Pract. 2014, 69, 86-104. [CrossRef]

41. Gonzalez-Feliu, J.; Chong, M.; Vargas-Florez, J., Jr.; de Brito, I.; Osorio-Ramirez, C.; Piatyszek, E.; Altamirano, R.Q. The Maturity of Humanitarian Logistics against Recurrent Crises. Soc. Sci. 2020, 9, 90. [CrossRef]

42. Mishkin, F.S. The Household Balance Sheet and the Great Depression. J. Econ. Hist. 1978, 38, 918-937. [CrossRef]

43. Romer, C.D. The Great Crash and the Onset of the Great Depression. Q. J. Econ. 1990, 105, 597-624. [CrossRef] 
44. Pennings, J.M.; Wansink, B.; Meulenberg, M.T. A note on modeling consumer reactions to a crisis: The case of the mad cow disease. Int. J. Res. Mark. 2002, 19, 91-100. [CrossRef]

45. Mian, A.; Sufi, A. The Great Recession: Lessons from Microeconomic Data. Am. Econ. Rev. 2010, 100, 51-56. [CrossRef]

46. Sharma, V.; Sonwalkar, J. Does Consumer Buying Behavior Change During Economic Crisis? Int. J. Econ. Bus. Adm. 2013, 1, 33-48. [CrossRef]

47. Voinea, L.; Filip, A. Analyzing the Main Changes in New Consumer Buying Behavior during Economic Crisis. Int. J. Econ. Pract. Theor. 2011, 1, 14-19.

48. Mansoor, D.; Jalal, A. The Global Business Crisis and Consumer Behavior: Kingdom of Bahrain as a Case Study. Int. J. Bus. Manag. 2010, 6, 104. [CrossRef]

49. Kaytaz, M.; Gul, M.C. Consumer response to economic crisis and lessons for marketers: The Turkish experience. J. Bus. Res. 2013, 67, 2701-2706. [CrossRef]

50. Turcinkova, J.; Stavkova, J.; Skalova, D.; Birciakova, N. Changes in Consumer Behavior in the EU after its Enlargement and due to the Economic Crisis. In Recent Advances in Economics, Management and Marketing, 1st ed.; WSEAS Press: Cambridge, MA, USA, 2014; pp. 78-85.

51. Swaminathan, V.; Lepkowska-White, E.; Rao, B.P. Browsers or Buyers in Cyberspace? An Investigation of Factors Influencing Electronic Exchange. J. Comput. Commun. 2006, 5, JCMC523. [CrossRef]

52. Anderson, W.P.; Chatterjee, L.; Lakshmanan, T.R. E-commerce, Transportation, and Economic Geography. Growth Change 2003, 34, 415-432. [CrossRef]

53. Rohm, A.J.; Swaminathan, V. A typology of online shoppers based on shopping motivations. J. Bus. Res. 2002, 57, 748-757. [CrossRef]

54. Farag, S.; Krizek, K.J.; Dijst, M. E-Shopping and its Relationship with In-store Shopping: Empirical Evidence from the Netherlands and the USA. Transp. Rev. 2006, 26, 43-61. [CrossRef]

55. Soopramanien, D.G.; Robertson, A. Adoption and usage of online shopping: An empirical analysis of the characteristics of "buyers" "browsers" and "non-internet shoppers". J. Retail. Consum. Serv. 2007, 14, 73-82. [CrossRef]

56. Weltevreden, J.W. Substitution or complementarity? How the Internet changes city centre shopping. J. Retail. Consum. Serv. 2007, 14, 192-207. [CrossRef]

57. Hsiao, M.-H. Shopping mode choice: Physical store shopping versus e-shopping. Transp. Res. Part E Logist. Transp. Rev. 2009, 45, 86-95. [CrossRef]

58. Cao, X.; Chen, Q.; Choo, S. Geographic Distribution of E-Shopping: Application of Structural Equation Models in the Twin Cities of Minnesota. Transp. Res. Rec. J. Transp. Res. Board 2013, 2383, 18-26. [CrossRef]

59. Lian, J.-W.; Yen, D.C. Online shopping drivers and barriers for older adults: Age and gender differences. Comput. Hum. Behav. 2014, 37, 133-143. [CrossRef]

60. Comi, A.; Nuzzolo, A. Exploring the Relationships Between e-shopping Attitudes and Urban Freight Transport. Transp. Res. Procedia 2016, 12, 399-412. [CrossRef]

61. Van Duin, R.; de Goffau, W.; Wiegmans, B.; Tavasszy, L.; Saes, M. Improving Home Delivery Efficiency by Using Principles of Address Intelligence for B2C Deliveries. Transp. Res. Procedia 2016, 12, 14-25. [CrossRef]

62. Suel, E.; Polak, J.W. Development of joint models for channel, store, and travel mode choice: Grocery shopping in London. Transp. Res. Part A Policy Pract. 2017, 99, 147-162. [CrossRef]

63. Zhai, Q.; Cao, X.; Mokhtarian, P.L.; Zhen, F. The interactions between e-shopping and store shopping in the shopping process for search goods and experience goods. Transportation 2016, 44, 885-904. [CrossRef]

64. Maat, K.; Konings, R. Accessibility or Innovation? Store Shopping Trips versus Online Shopping. Transp. Res. Rec. 2018, 2672, 1-10. [CrossRef]

65. Hood, N.; Urquhart, R.; Newing, A.; Heppenstall, A. Sociodemographic and spatial disaggregation of e-commerce channel use in the grocery market in Great Britain. J. Retail. Consum. Serv. 2020, 55, 102076. [CrossRef]

66. Loo, B.P.Y.; Wang, B. Factors associated with home-based e-working and e-shopping in Nanjing, China. Transportation 2017, 45, 365-384. [CrossRef]

67. Zhen, F.; Cao, X.; Mokhtarian, P.L.; Xi, G. Associations Between Online Purchasing and Store Purchasing for Four Types of Products in Nanjing, China. Transp. Res. Rec. J. Transp. Res. Board 2016, 2566, 93-101. [CrossRef]

68. Kirby-Hawkins, E.; Birkin, M.; Clarke, G. An investigation into the geography of corporate e-commerce sales in the UK grocery market. Environ. Plan. B Anal. City Sci. 2018, 46, 1148-1164. [CrossRef]

69. Harman, H.H. Modern Factor Analysis; The University of Chicago Press: Chicago, IL, USA, 1976.

70. Johns Hopkins Coronavirus Resource Center. 2020. Available online: https://coronavirus.jhu.edu/map.html (accessed on 20 August 2020).

71. Katona, G. Psychology and Consumer Economics. J. Consum. Res. 1974, 1, 1-8. [CrossRef]

72. O'Guinn, T.C.; Faber, R.J. Compulsive Buying: A Phenomenological Exploration. J. Consum. Res. 1989, 16, 147-157. [CrossRef]

73. Kitamura, R.; Mokhtarian, P.L.; Daidet, L. A micro-analysis of land use and travel in five neighborhoods in the San Francisco Bay Area. Transportation 1997, 24, 125-158. [CrossRef]

74. Mokhtarian, P.L.; Ory, D.T.; Cao, X. Shopping-Related Attitudes: A Factor and Cluster Analysis of Northern California Shoppers. Environ. Plan. B Plan. Des. 2009, 36, 204-228. [CrossRef] 
75. Mokhtarian, P.L.; Tang, W.; Hess, S.; Daly, A. Trivariate Probit Models of Pre-Purchase/Purchase Shopping Channel Choice: Clothing Purchases in Northern California; Research Report-UCD-ITS-RR-11-15; University of California: Davis, CA, USA, 2011.

76. Trump, D.J. Memorandum on Reforming Developing-Country Status in the World Trade Organization. Online by Gerhard Peters and John T. Woolley, The American Presidency Project. 2019. Available online: https://www.presidency.ucsb.edu/node/333749 (accessed on 20 July 2021).

77. World Trade Organization. E-Commerce, Trade and the COVID-19 Pandemic, 4 May 2020. p. 8. Available online: https:/ / www.wto.org/english/tratop_e/covid19_e/ecommerce_report_e.pdf?fbclid=IwAR0y1TcnM_BKVhvSX-M5DBk_ nSZgdqyqRzmIlmITPwXfWNMgFn7bhUaN6-g (accessed on 20 July 2021).

78. Statista, 2020. Share of Consumers in the United States Who Believe They Might Purchase Prescriptions and OTC Medication Online if Confined at Home due to the Coronavirus as of March 2020. Available online: https://www.statista.com/statistics/11 06468/likelihood-online-medication-purchase-due-to-coronavirus-home-usa/?fbclid=IwAR2n42T9gUtIVRb-AxWHMv9d2 EtB6JQwHDspFXTwmn4O9nV86B-KE6lhgag (accessed on 20 July 2021).

79. He, X.; Lau, E.H.Y.; Wu, P.; Deng, X.; Wang, J.; Hao, X.; Lau, Y.C.; Wong, J.Y.; Guan, Y.; Tan, X.; et al. Temporal dynamics in viral shedding and transmissibility of COVID-19. Nat. Med. 2020, 26, 672-675. [CrossRef]

80. Holguín-Veras, J.; Amaya-Leal, J.; Cantillo, V.; Van Wassenhove, L.N.; Aros-Vera, F.; Jaller, M. Econometric estimation of deprivation cost functions: A contingent valuation experiment. J. Oper. Manag. 2016, 45, 44-56. [CrossRef]

81. Cantillo, V.; Serrano, I.; Macea, L.F.; Holguín-Veras, J. Discrete choice approach for assessing deprivation cost in humanitarian relief operations. Socio-Econ. Plan. Sci. 2018, 63, 33-46. [CrossRef]

82. Yelp Economic Average, 2020. Yelp: Local Economic Impact Report, Updated 25 June 2020. Available online: https://www. yelpeconomicaverage.com/yelp-coronavirus-economic-impact-report.html (accessed on 20 July 2021).

83. Becker, G.S. Irrational Behavior and Economic Theory. J. Politi-Econ. 1962, 70, 1-13. [CrossRef]

84. McFadden, D. Economic Choices. Am. Econ. Rev. 2001, 91, 351-378. [CrossRef]

85. Liren, X.; Junmei, C.; Mingqin, Z. Research on Panic Purchase's Behavior Mechanism. In Proceedings of the 9th International Conference on Innovation \& Management, Eindhoven, The Netherlands, 14-16 November 2012; pp. $1332-1335$.

86. Pepe, E.; Bajardi, P.; Gauvin, L.; Privitera, F.; Lake, B.; Cattuto, C.; Tizzoni, M. COVID-19 outbreak response: A first assessment of mobility changes in Italy following national lockdown. medRxiv 2020. [CrossRef]

87. Tirachini, A.; Cats, O. COVID-19 and Public Transportation: Current Assessment, Prospects, and Research Needs. J. Public Transp. 2020, 22, 1-21. [CrossRef]

88. Kaiser, H.F. The varimax criterion for analytic rotation in factor analysis. Psychometrika 1958, 23, 187-200. [CrossRef]

89. Fortune.com. Walmart's Online Sales Surge during the Pandemic, Bolstering Its Place as a Strong No. 2 to Amazon. 2020. Available online: https:/ / fortune.com/2020/05/19/walmart-online-sales-amazon-ecommerce/ (accessed on 25 July 2021).

90. Wang, X.; Kim, W.; Holguín-Veras, J.; Schmid, J. Adoption of delivery services in light of the COVID pandemic: Who and how long? Transp. Res. Part A Policy Pract. 2021, 154, 270-286. [CrossRef]

91. Wicaksono, S.; Lin, X.; Tavasszy, L.A. Market potential of bicycle crowdshipping: A two-sided acceptance analysis. Res. Transp. Bus. Manag. 2021, 100660. [CrossRef] 